\title{
LANL NPB Project: Ion Source Selection and Development Path
}

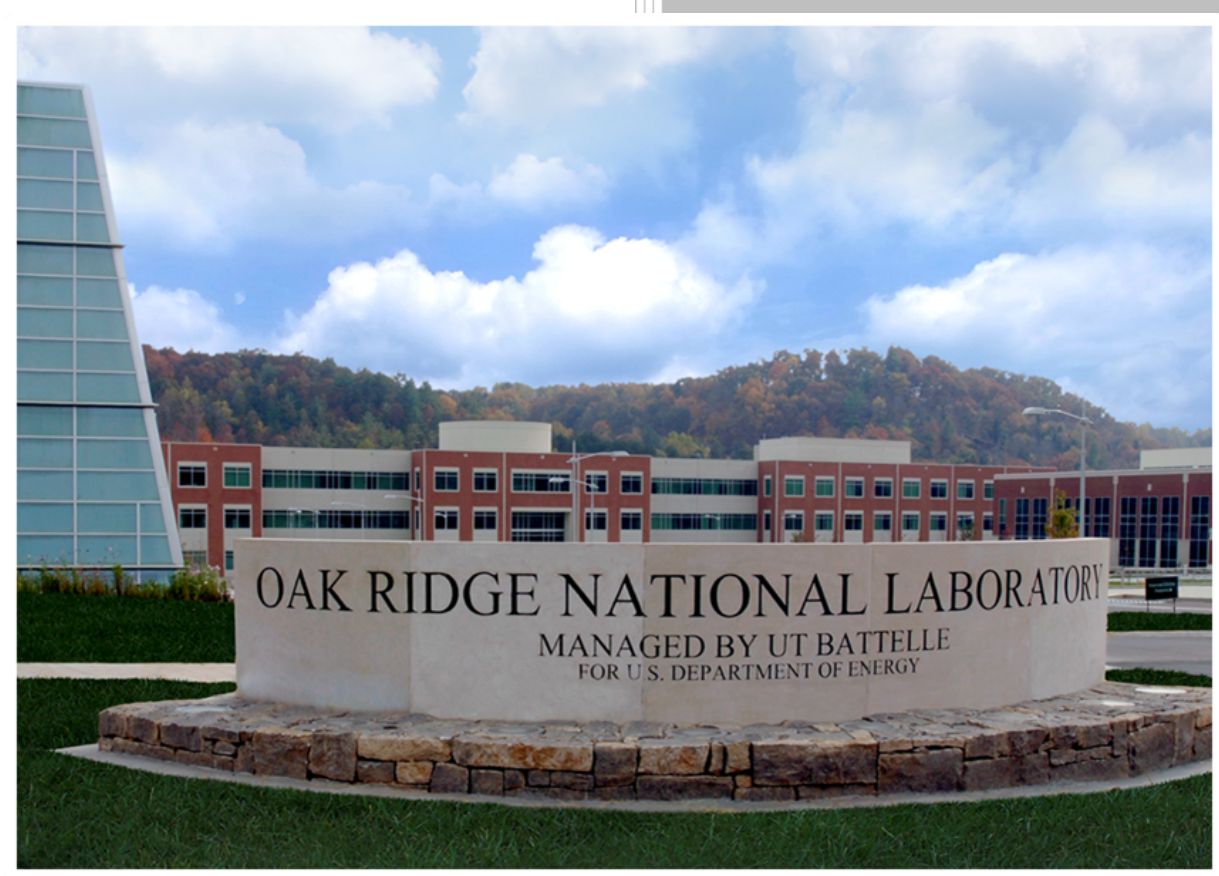

Approved for public release.

Distribution is unlimited.
Robert Welton

Baoxi Han

Martin Stockli

Ilija Draganic

Rob Saethre Oscar Martinez Morgan Dehnel Stephane Melanson Nikolai Yampolsky Dave Potkins

April 25, 2019 


\title{
DOCUMENT AVAILABILITY
}

Reports produced after January 1, 1996, are generally available free via US Department of Energy (DOE) SciTech Connect.

Website www.osti.gov

Reports produced before January 1, 1996, may be purchased by members of the public from the following source:

\author{
National Technical Information Service \\ 5285 Port Royal Road \\ Springfield, VA 22161 \\ Telephone 703-605-6000 (1-800-553-6847) \\ TDD 703-487-4639 \\ Fax 703-605-6900 \\ E-mail info@ntis.gov \\ Website http://classic.ntis.gov/
}

Reports are available to DOE employees, DOE contractors, Energy Technology Data Exchange representatives, and International Nuclear Information System representatives from the following source:

Office of Scientific and Technical Information

PO Box 62

Oak Ridge, TN 37831

Telephone 865-576-8401

Fax 865-576-5728

E-mail reports@osti.gov

Website http://www.osti.gov/contact.html

This report was prepared as an account of work sponsored by an agency of the United States Government. Neither the United States Government nor any agency thereof, nor any of their employees, makes any warranty, express or implied, or assumes any legal liability or responsibility for the accuracy, completeness, or usefulness of any information, apparatus, product, or process disclosed, or represents that its use would not infringe privately owned rights. Reference herein to any specific commercial product, process, or service by trade name, trademark, manufacturer, or otherwise, does not necessarily constitute or imply its endorsement, recommendation, or favoring by the United States Government or any agency thereof. The views and opinions of authors expressed herein do not necessarily state or reflect those of the United States Government or any agency thereof. 
Neutron Sciences Directorate

Research Accelerator Division

\title{
LANL NPB Project: Ion Source Selection and Development Path
}

\author{
Robert Welton \\ Baoxi Han \\ Martin Stockli \\ Ilija Draganic \\ Rob Saethre \\ Oscar Martinez \\ Morgan Dehnel \\ Stephane Melanson \\ Nikolai Yampolsky \\ Dave Potkins
}

April 26, 2019

Prepared by

OAK RIDGE NATIONAL LABORATORY

Oak Ridge, TN 37831-6283

managed by

UT-BATTELLE, LLC 
for the US DEPARTMENT OF ENERGY under contract DE-AC05-00OR22725 


\title{
CONTENTS
}

1. Survey of existing pulsed and $\mathrm{DC} \mathrm{H}^{-}$ion sources

2. The baseline D-Pace $15 \mathrm{~mA}$ steady-state source

3. TRIUMF proof-of-principle $60 \mathrm{~mA}$ experiment

4. Sumitomo cesiation test of the D-Pace source

5. Development path towards an operational $>15 \mathrm{~mA} \mathrm{DC} \mathrm{H}^{-}$ion source

a. Extraction simulations: modeling higher current and voltage beam extraction from the upgraded D-Pace source

b. Mechanical considerations: thermal modeling of elevated heat loads on the upgraded DPace source

c. Electrical considerations: Specifying the required power supplies and pulser for the upgraded D-Pace source

6. Proposed path forward for the LANL NPB ion source project

\begin{abstract}
The ORNL team will provide LANL with a scoping / feasibility study of $\mathrm{H}^{-}$sources which could potentially be developed to approach the goal of producing a single high-duty-factor $\mathrm{H}^{-}$beam of up to $\sim 100 \mathrm{~mA}$ suitable for acceleration by an RFQ. Currently, no existing $\mathrm{H}^{-}$sources have been shown to operate anywhere near this goal so the study will focus on identifying the most promising approach and define the existing option space. Attention will be given to source concepts which are most likely to be scalable to continuous beam operation while offering lower-risk, lower duty-factor or beam current operation in the shorter term. The study will discuss the technology within this option space, tradeoffs and identify the best path forward. Once the best option is identified, an estimate of the expected output emittance, beam current, achievable beam duty-factor, hydrogen and cesium consumption rates, physical size and weight estimates of the source and supporting subsystems will be provided. This work will lay the foundation for developing a conceptual source design in Development 2 which will inform an actual mechanical design that will be used to either construct a prototype source or modify an existing source as part of a future technology development program for the project. The relative technology development risk and mitigations would also be defined
\end{abstract}


for the candidate ion source technologies for a TRL 5 demonstration. Risk analysis for later TRL 6 phases and beyond would be part of a later phase of the project.

\section{SURVAY OF EXISTING H' ION SOURCES}

Ion sources which produce beams of negative hydrogen $\left(\mathrm{H}^{-}\right)$can be broadly classified into large multi extraction aperture sources for fusion applications and smaller, single aperture, sources used primarily for injection into particle accelerators. Large multi-aperture ion sources can be used to produce beams of $\mathrm{H}^{-}$ and $\mathrm{D}^{-}$of several hundred amperes, with large cross-sectional areas of a few $\mathrm{m}^{2}$. Such beams can be accelerated to $\sim 1 \mathrm{MeV}$, neutralized and injected, through the confinement fields, of a burning fusion plasma thereby delivering MWs of heating power [1]. The smaller single aperture $\mathrm{H}^{-}$sources are typically used to inject particle accelerators which require negative ion beams. Such instruments include DC (direct current) accelerators such as cyclotrons, tandems and ion implanters and pulsed, high energy machines like the Spallation Neutron Sources and the Large Hadron Collider [2]. These beams typically have milliampere currents with a cross sectional area of $\sim \mathrm{cm}^{2}$ and an emittance of $0.1-0.3 \pi \mathrm{mm}$ mrad and can be accelerated up to $\mathrm{GeV}$ or even $\mathrm{TeV}$ energies. Figure 1 shows cross sectional views of representative examples of these sources. A full, easily accessible, online database of the literature associated with nearly all the ion sources studied here can be found in the Proceedings of the International Symposium on Negative Ions and Beams and the International Conference on Ion Sources [3]. It is beyond the scope of this report to discuss the engineering or operating principles of these ion sources in any detail but that information can be found in recent survey papers [2].

In this study we focus on the smaller, single aperture $\mathrm{H}^{-}$ion sources and consider the tradeoffs as they may apply to the LANL NB project. We will first consider pulsed sources which are primarily used for charge exchange injection into synchrotrons and storage rings. Table I shows a listing of such operational pulsed sources currently employed in major accelerator facilities worldwide as well as their nominal operating parameters [2]. The last column shows the average $\mathrm{H}^{-}$beam current produced by each ion source. Average current is the product of the beam duty-factor (pulse width $\mathrm{x}$ repetition rate) and the amplitude of the beam current pulse and is useful to calculate beam power on target.

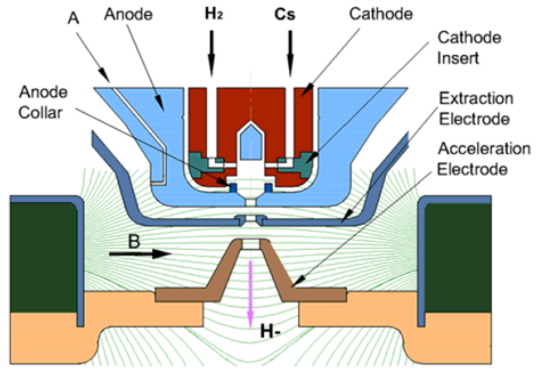

Penning sources

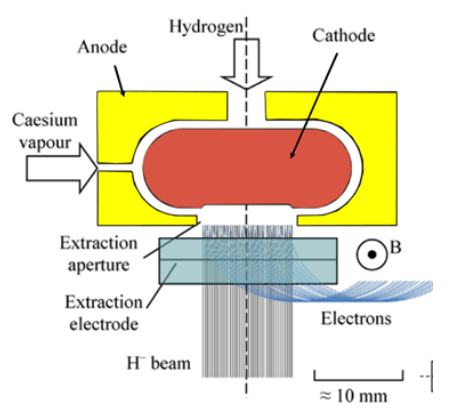

Magnetron sources 


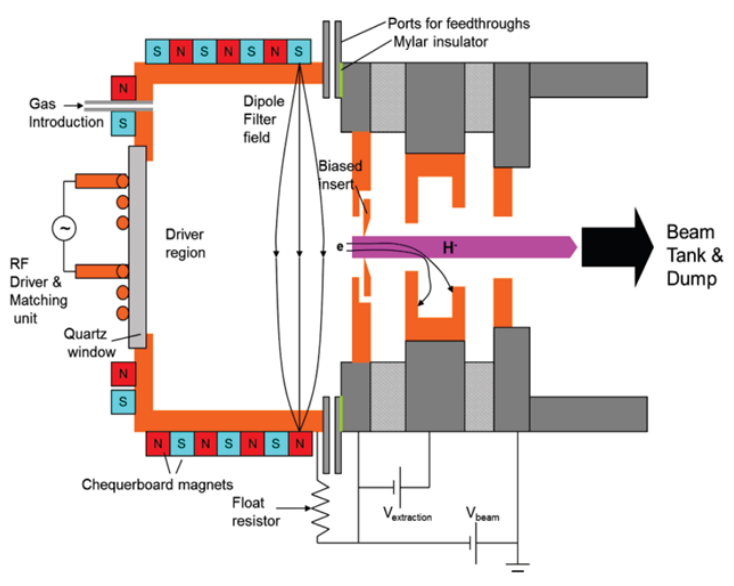

RF multicusp sources

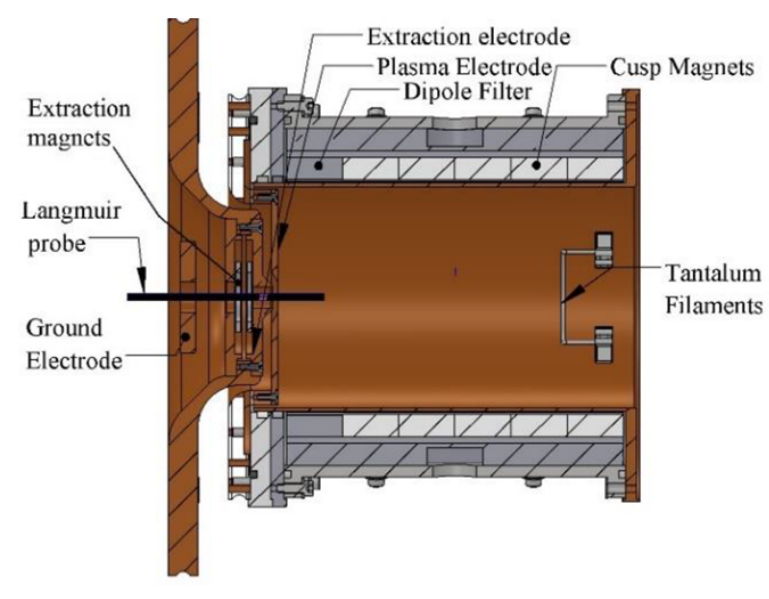

Filament multicusp sources

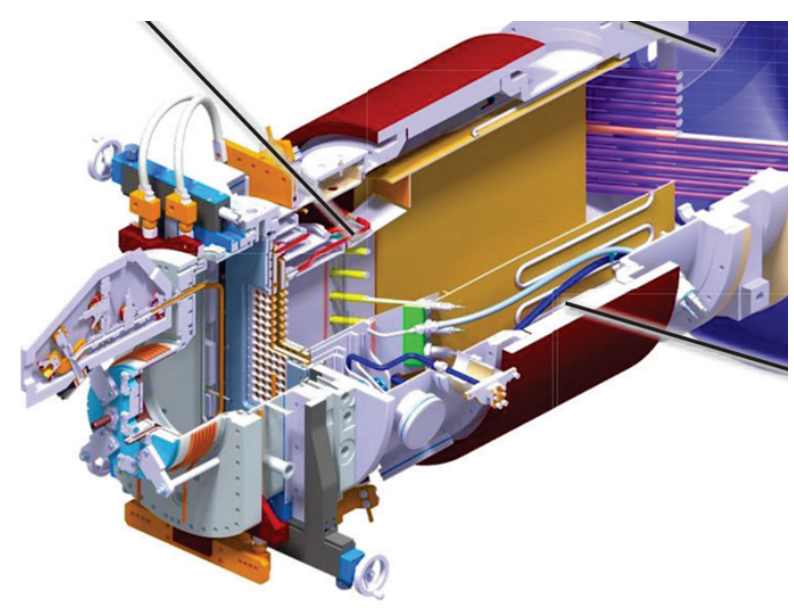

Large NBI ion sources

Fig. 1 Cross sectional views common $\mathrm{H}^{-}$ion sources. Figures courtesy of Y. Belchenko, R. McAdams, M. Dehnel, W. Kaus, D. Faircloth Table I. Listing of operational pulsed $\mathrm{H}^{-}$ion source in use at accelerator facilities.

\begin{tabular}{|c|c|c|c|c|c|c|c|}
\hline $\begin{array}{l}\boldsymbol{H} \text {-Source } \\
\text { [reference] }\end{array}$ & Method & $\begin{array}{c}\text { Discharge \& } \\
\text { Repetition Rate }\end{array}$ & $\begin{array}{c}\text { Plasma } \\
\text { \& Beam } \\
\text { Duty } \\
\text { Factors }\end{array}$ & $\begin{array}{c}\text { Average } \\
\text { Beam } \\
\text { Pulse } \\
\text { Current }\end{array}$ & $\begin{array}{c}\text { Extrac- } \\
\text { tion } \\
\text { Aper- } \\
\text { ture }\end{array}$ & $\begin{array}{c}\text { Service } \\
\text { Cycle/ } \\
\text { Lifetime }\end{array}$ & $\begin{array}{c}\text { Ave beam } \\
\text { current }\end{array}$ \\
\hline $\begin{array}{l}\text { BNL [4] } \\
\text { Operation }\end{array}$ & $\begin{array}{l}\text { Magnetron } \\
\text { Surface }\end{array}$ & $\begin{array}{r}12-14 \mathrm{~A} ; 130 \mathrm{~V} \\
@ 7.5 \mathrm{~Hz}\end{array}$ & $\begin{array}{l}0.50 \% \\
0.44 \%\end{array}$ & $\begin{array}{c}110-120 \\
\mathrm{~mA}\end{array}$ & $\begin{array}{c}2.8 \mathrm{~mm} \\
\varnothing\end{array}$ & $\begin{array}{l}\text { 6-8 } \\
\text { months }\end{array}$ & $0.5 \mathrm{~mA}$ \\
\hline $\begin{array}{l}\text { FNAL[5] } \\
\text { Operation }\end{array}$ & $\begin{array}{l}\text { Magnetron } \\
\text { Surface }\end{array}$ & $\begin{array}{r}15 \mathrm{~A} ; 180 \mathrm{~V} \\
@ 15 \mathrm{~Hz}\end{array}$ & $\begin{array}{c}0.345 \% \\
0.3 \%\end{array}$ & $80 \mathrm{~mA}$ & $\begin{array}{c}3.2 \mathrm{~mm} \\
\varnothing\end{array}$ & 9 months & $0.3 \mathrm{~mA}$ \\
\hline $\begin{array}{l}\text { ISIS [6] } \\
\text { Operation }\end{array}$ & $\begin{array}{l}\text { Penning } \\
\text { Surface }\end{array}$ & $\begin{array}{c}55 \mathrm{~A} ; 70 \mathrm{~V} \\
\text { @ } 50 \mathrm{~Hz}\end{array}$ & $\begin{array}{l}3.75 \% \\
1.1 \%\end{array}$ & $55 \mathrm{~mA}$ & $\begin{array}{l}0.6 \times 10 \\
\mathrm{~mm}^{2} \text { slit }\end{array}$ & 5 weeks & $0.6 \mathrm{~mA}$ \\
\hline $\begin{array}{l}\text { CSNS[7] } \\
\text { Phase I }\end{array}$ & $\begin{array}{l}\text { Penning } \\
\text { Surface }\end{array}$ & $\begin{array}{c}\sim 50 \mathrm{~A} ; \sim 100 \mathrm{~V} \\
\text { @ } 25 \mathrm{~Hz}\end{array}$ & $\begin{array}{l}1.5 \% \\
1.25 \%\end{array}$ & $50 \mathrm{~mA}$ & $\begin{array}{l}0.6 \times 10 \\
\mathrm{~mm}^{2} \text { slit }\end{array}$ & $1 \mathrm{month}$ & $0.6 \mathrm{~mA}$ \\
\hline
\end{tabular}




\begin{tabular}{|c|c|c|c|c|c|c|c|}
\hline $\begin{array}{l}\text { INR RAS } \\
\text { linac }[8]\end{array}$ & $\begin{array}{l}\text { Penning } \\
\text { Surface }\end{array}$ & $\begin{array}{r}100 \mathrm{~A} ; 120 \mathrm{~V} \\
@ 50 \mathrm{~Hz}\end{array}$ & $\begin{array}{l}1 \% \\
1 \%\end{array}$ & $20 \mathrm{~mA}$ & $\begin{array}{l}1.0 \times 10 \\
\mathrm{~mm}^{2} \text { slit }\end{array}$ & & $0.2 \mathrm{~mA}$ \\
\hline $\begin{array}{r}\text { LANSCE } \\
\text { Operation } \\
{[9]}\end{array}$ & $\begin{array}{l}\text { Filament } \\
\text { driven } \\
\text { converter }\end{array}$ & $\begin{array}{c}30-35 \mathrm{~A} ; 180 \mathrm{~V} \\
\text { @ } 120 \mathrm{~Hz}\end{array}$ & $\begin{array}{l}10 \% \\
7.6 \%\end{array}$ & $16-18 \mathrm{~mA}$ & $\begin{array}{c}9.8 \mathrm{~mm} \\
\varnothing\end{array}$ & 4 weeks & $2 \mathrm{~mA}$ \\
\hline $\begin{array}{l}\text { SNS } \\
\text { Operation } \\
\qquad[10]\end{array}$ & $\begin{array}{c}\text { Internal RF } \\
\text { Antenna }\end{array}$ & $\begin{array}{c}\text { DC } 300 \mathrm{~W} \\
13 \mathrm{MHz} \& 60 \mathrm{~Hz} \\
60 \mathrm{~kW} 2 \mathrm{MHz} \\
\end{array}$ & $\begin{array}{c}6 \% \\
5.94 \%\end{array}$ & $>60 \mathrm{~mA}$ & $7 \mathrm{~mm} \varnothing$ & 14 weeks & $3.6 \mathrm{~mA}$ \\
\hline $\begin{array}{l}\text { J-PARC } \\
\text { Operation } \\
{[11]} \\
\end{array}$ & $\begin{array}{c}\text { Internal RF } \\
\text { antenna }\end{array}$ & $\begin{array}{c}\text { DC } 50 \mathrm{~W} 30 \mathrm{MHz} \\
\& 25 \mathrm{~Hz} 22 \mathrm{~kW} \\
2 \mathrm{MHz} \\
\end{array}$ & $\begin{array}{c}2 \% \\
1.25 \%\end{array}$ & $47 \mathrm{~mA}$ & $9 \mathrm{~mm} \varnothing$ & 11 weeks & $0.9 \mathrm{~mA}$ \\
\hline $\begin{array}{l}\text { CERN } \\
\text { Linac4 } \\
\\
\end{array}$ & $\begin{array}{c}\text { External } \\
\text { RF antenna }\end{array}$ & $\begin{array}{c}0.8 \mathrm{~Hz} 40 \mathrm{~kW} \\
2 \mathrm{MHz} \\
\text { Pulsed } \mathrm{H}_{2} \\
\end{array}$ & $\begin{array}{l}0.07 \% \\
0.05 \%\end{array}$ & $45 \mathrm{~mA}$ & $\begin{array}{c}5.5 \mathrm{or} \\
6.5 \mathrm{~mm} \\
\varnothing\end{array}$ & 7 weeks & $0.02 \mathrm{~mA}$ \\
\hline
\end{tabular}

Table II shows a similar compilation of single aperture, steady-state (continuous beam) ion sources. This type of source is mostly used in conjunction with cyclotrons providing $\mathrm{H}^{-}$ions to facilitate extraction of high energy beams from the accelerator through stripping. Also included on the table are several near steady-state, experimental, sources developed as drivers for the larger fusion ion sources which have not been developed for single aperture injection into accelerators. The later sources are denoted by asterisks in the table.

Fig. 2 shows the average beam power which could be delivered to a target by $100 \mathrm{MeV}$ acceleration of beams produced from each of the sources shown in tables I and II. The table also includes a data point from the acceleration of a $60 \mathrm{~mA}$ DC beam produced in a recent TRIUMF experiment that will be discussed in detail in section 3 of this report. It is clear from the figure that overall, the pulsed sources deliver much less average current than those developed for DC-operation. Of the operational DC sources most are or have been derived from the D-Pace / TRIUMF filament driven multicusp source. We believe this source offers the best solution for the LANL NPB project since the baseline ion source is commercially available, utilized in many facilities and has shown it can deliver reliable beams of sufficient lifetime and emittance. We also believe it has the greatest potential of being upgraded to higher beam currents. For reference, the most intense operational pulsed $\mathrm{H}^{-}$ion source (SNS) can deliver about $0.3 \mathrm{MW}$ at $100 \mathrm{MeV}$ on target versus the baseline D-Pace source which can reliably deliver about $1.5 \mathrm{MW}$ of power with the future potential of delivering 5+ MW by following the approach described in this report.

Table II. Listing of steady-state $\mathrm{H}^{-}$ion source in use at accelerator facilities worldwide. ${ }^{*}$ Denote source which have not been developed for single aperture injection into an accelerator.

\begin{tabular}{|c|c|c|c|c|c|c|c|}
\hline $\begin{array}{c}\mathbf{H}^{-} \\
\text {Source }\end{array}$ & Method & $\begin{array}{c}\text { Discharg } \\
\text { e Power: } \\
\text { Arc or RF }\end{array}$ & $\begin{array}{c}\text { Duty } \\
\text { Factor }\end{array}$ & $\begin{array}{c}\text { Beam } \\
\text { Current } \\
\text { or density }\end{array}$ & $\begin{array}{c}\text { Extractio } \\
\mathbf{n} \\
\text { Aperture }\end{array}$ & $\begin{array}{c}\text { Service } \\
\text { Cycle/ } \\
\text { Lifetime* }^{*}\end{array}$ & $\begin{array}{c}\text { Use } \\
\text { of Cs }\end{array}$ \\
\hline $\begin{array}{c}\text { D-Pace } \\
\text { filament } \\
{[13]}\end{array}$ & $\begin{array}{c}\text { Filament } \\
\text { multicusp }\end{array}$ & $\begin{array}{c}33 \mathrm{~A} \\
/ 120 \mathrm{~V}\end{array}$ & $100 \%$ & $15 \mathrm{~mA}$ & $\varnothing 13 \mathrm{~mm}$ & $350 \mathrm{~h}$ & no \\
\hline $\begin{array}{c}\text { TRIUMF } \\
{[14]}\end{array}$ & $\begin{array}{c}\text { Filament } \\
\text { multicusp }\end{array}$ & $\begin{array}{c}9- \\
30 \mathrm{~A} / 120 \mathrm{~V}\end{array}$ & $100 \%$ & $\sim 10 \mathrm{~mA}$ & $\varnothing 13 \mathrm{~mm}$ & $350 \mathrm{~h}+$ & no \\
\hline
\end{tabular}




\begin{tabular}{|c|c|c|c|c|c|c|c|}
\hline $\begin{array}{c}\text { BINP } \\
\text { Penning } \\
\text { [15] }\end{array}$ & $\begin{array}{l}\text { Penning } \\
\text { Surface }\end{array}$ & $\begin{array}{l}\sim 10 \mathrm{~A} / \\
90 \mathrm{~V}\end{array}$ & $100 \%$ & $8-25 \mathrm{~mA}$ & $\varnothing 5 \mathrm{~mm}$ & $\begin{array}{l}\text { Tested for a } \\
\text { few hours at } \\
\text { high current }\end{array}$ & yes \\
\hline $\begin{array}{c}\text { Culham } \\
\text { SNIF RF } \\
\text { source* } \\
{[16]} \\
\end{array}$ & $\begin{array}{l}\text { RF volume } \\
\text { source }\end{array}$ & $3.5 \mathrm{~kW}$ & $\begin{array}{l}\text { Long } \\
\text { multi- } \\
\text { second } \\
\text { pulses }\end{array}$ & $6 \mathrm{~mA}$ & $\begin{array}{c}\varnothing 7 \mathrm{~mm} \\
\text { Normally } \\
\text { large grid }\end{array}$ & Brief testing & no \\
\hline $\begin{array}{c}\text { Argonne / } \\
\text { Saclay } \\
2.45 \mathrm{GHz} \\
{[17]} \\
\end{array}$ & $\begin{array}{l}\text { Mircowave } \\
\text { source }\end{array}$ & $\sim 1 \mathrm{~kW}$ & $\begin{array}{c}10- \\
100 \%\end{array}$ & $3-5 \mathrm{~mA}$ & $\varnothing 5 \mathrm{~mm}$ & $\begin{array}{c}\text { Brief testing } \\
\text { no }\end{array}$ & no \\
\hline $\begin{array}{c}\text { Sumitomo } \\
\text { source } \\
{[18]}\end{array}$ & D-Pace source & $\begin{array}{l}23 \mathrm{~A} / \\
120 \mathrm{~V}\end{array}$ & $100 \%$ & $16 \mathrm{~mA}$ & $\varnothing 13 \mathrm{~mm}$ & unknown & yes \\
\hline $\begin{array}{c}\text { D-Pace RF } \\
\text { source } \\
{[19]}\end{array}$ & $\begin{array}{c}\text { D-Pace JYU } \\
\text { collaboration }\end{array}$ & $3.5 \mathrm{~kW}$ & $100 \%$ & $7.5 \mathrm{~mA}$ & $\varnothing 13 \mathrm{~mm}$ & $>1$ year & no \\
\hline $\begin{array}{c}\text { IPP RF } \\
\text { source* } \\
{[20]}\end{array}$ & $\begin{array}{c}\mathrm{Cs} / \mathrm{RF} \text { large } \\
\text { multiaperture } \\
\text { bucket source } \\
\text { of NBI }\end{array}$ & $100 \mathrm{~kW}$ & $\begin{array}{l}1 \text { hour } \\
\text { shots }\end{array}$ & $\begin{array}{c}30 \mathrm{~mA} / \mathrm{cm} 2 \\
46 \mathrm{~mA}\end{array}$ & $\begin{array}{l}\varnothing 14 \mathrm{~mm} \\
\text { Normally } \\
\text { large grid }\end{array}$ & long & yes \\
\hline $\begin{array}{c}\text { BINP RF } \\
\text { source* } \\
{[21]}\end{array}$ & $\begin{array}{c}\mathrm{Cs} / \mathrm{RF} \text { large } \\
\text { multiaperture } \\
\text { bucket source } \\
\text { of } \mathrm{NBI}\end{array}$ & $34 \mathrm{~kW}$ & $\begin{array}{l}25 \mathrm{~s} \\
\text { shots }\end{array}$ & $30 \mathrm{~mA} / \mathrm{cm} 2$ & $\begin{array}{l}\text { Large } \\
\text { grid }\end{array}$ & long & yes \\
\hline
\end{tabular}

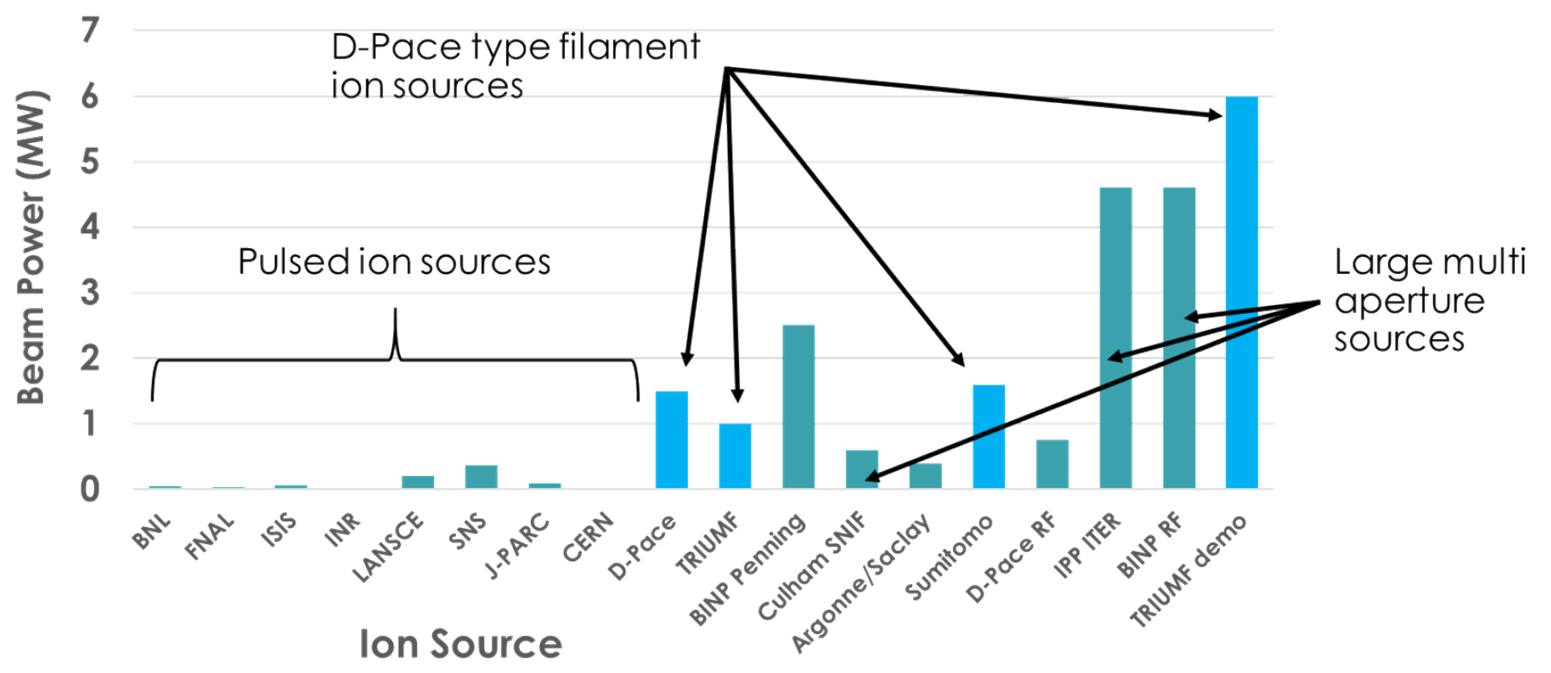


Fig. 2. Average beam power delivered to a target at $100 \mathrm{MeV}$ for each of the sources listed in Tables I and II as well as the result from a recent TRIUMF demonstration experiment (section 3).

\section{THE BASELINE D-PACE 15 mA DC ION SOURCE}

The D-Pace filament driven, multicusp source is currently commercially available and used in many of accelerator facilities worldwide: FNAL, ACSI (Canada), SPECT tracer cyclotrons, BEST Cyclotrons (Canada), CNEA Argentina, CIAE, IBA, Sumitomo Heavy Ind, Kotron-30 installed at KAERI, Tri-Alpha (BNCT), as well as in the TRIUMF cyclotrons $[13,22]$. Many of these facilities use the baseline D-Pace source or a variation of it operating with $\mathrm{H}^{-}$beams currents up to $15 \mathrm{~mA}$. The baseline source filament lifetime is greater than $5250 \mathrm{~mA}$-hours and the beam has normalized 4-rms emittance $<1 \pi \mathrm{mm} \mathrm{mrad}$ suitable for the LANL NPB project [13]. In addition, TRIUMF has recently conducted a proof-of-principle experiment showing that DC beams of up to $60 \mathrm{~mA}$ could be extracted from a modified D-Pace ion source. We propose pursuing this solution for the LANL NPB project since, even the baseline source, has been proven to deliver $4 \mathrm{x}$ more average beam current than, for example, the SNS source, from a well characterized and cost-effective platform. It also offers best possibility of scaling to the higher DC beam currents desired by the LANL NPB program.

Fig. 3 shows a photograph of the baseline D-Pace source configuration and associated test chamber. Table 3 shows the source specifications which are available through the D-Pace website [13] and Fig. 4 shows the extracted $\mathrm{H}^{-}$beam current as a function of $\mathrm{H}_{2}$ gas feed rate and filament arc current. Table 4 shows typical source parameters during a startup as the arc current is brought up to full operating conditions. One should note that as the arc power is increased the filament current is reduced to maintain constant filament temperature. Communications with D-Pace shows the length of time for a cold start up is typically about 5 minutes which could be reduced with automation. A warm startup where the filament was kept warm generally takes about 1 minute. Fig. 5 shows emittance measurement data from taken from the D-Pace test stand that shows that the source has a normalized 1-rms emittance $0.17 \pi \mathrm{mm} \operatorname{mrad}$ [23]. Fig. 6 shows the electrical diagram for a typical D-Pace source installation, with a total electrical service to the source being $\sim 20 \mathrm{~kW}[13]$. 


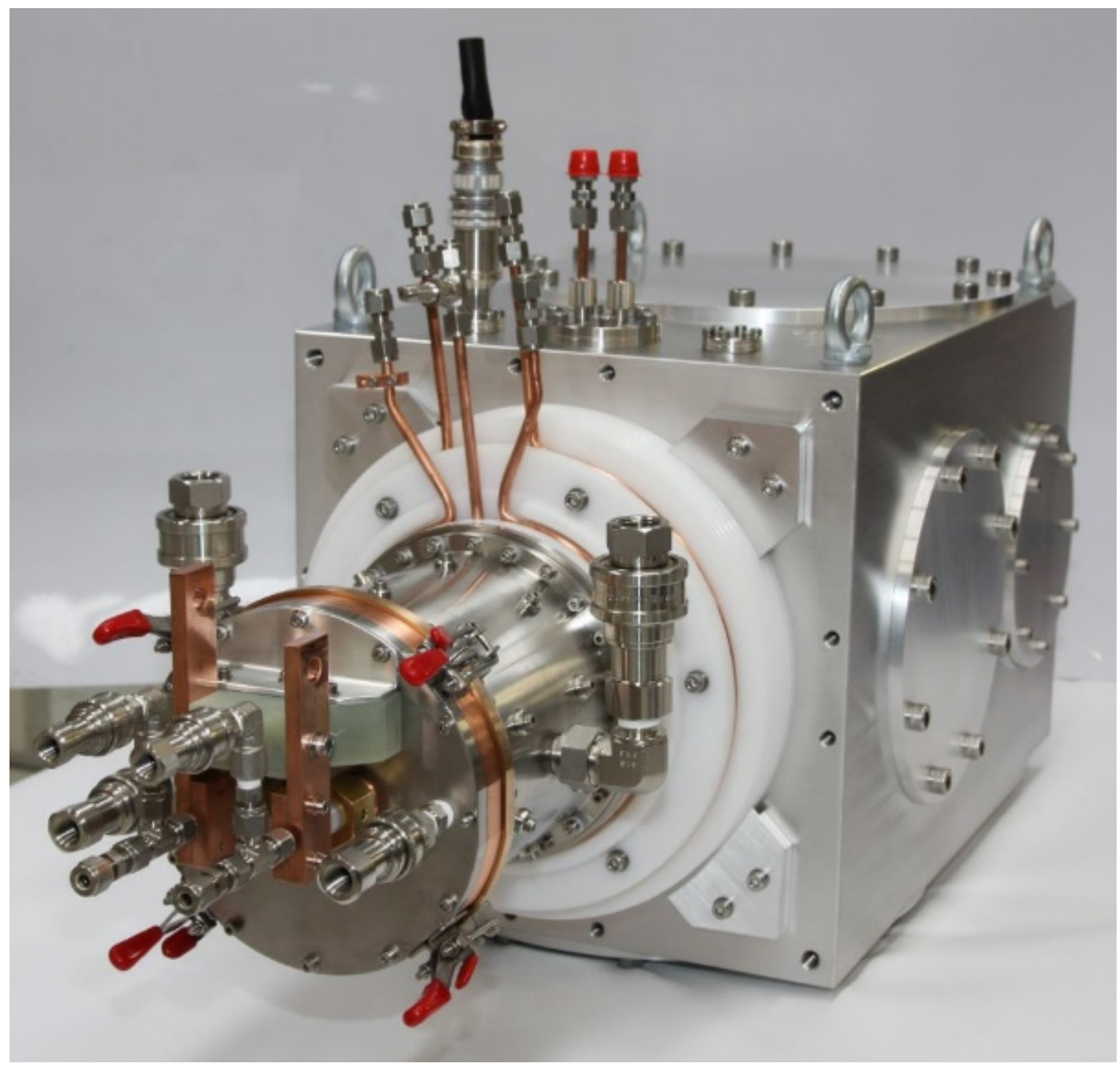

Fig. 3. The baseline D-Pace $15 \mathrm{~mA}$ multicusp, filament-driven source configuration and associated test chamber. Courtesy of D-Pace, Inc.

Table III. The baseline D-Pace 15mA source specifications. Courtesy of D-Pace, Inc. 


\begin{tabular}{|ll|}
\hline SPECIFICATIONS: \\
\hline ION SOURCE \\
\hline Particle Type & $\mathrm{H}^{-}$ \\
\hline Beam Current & 0 to $15 \mathrm{~mA}$ \\
\hline Beam Kinetic Energy & 20 to $30 \mathrm{keV}$ \\
\hline Normalized 4rms Emittance & $<1 \mathrm{~mm} \cdot \mathrm{mrad}$ \\
\hline Beam Purity & $>99 \%$ \\
\hline Filament Lifetime & $>5250 \mathrm{~mA} \cdot$ hours \\
\hline Beam Current Stability & $\pm 1 \%$ over 24 hours \\
\hline POWER SUPPLIES & \\
\hline Bias Supply & $40 \mathrm{~mA}, 30 \mathrm{keV}$ \\
\hline Arc Supply & $50 \mathrm{~A}, 200 \mathrm{~V}$ \\
\hline Filament Supply & $400 \mathrm{~A}, 10 \mathrm{~V}$ \\
\hline Plasma Lens & $42 \mathrm{~A}, 10 \mathrm{~V}$ \\
\hline Extraction Lens & $150 \mathrm{~mA}, 5 \mathrm{kV}$ \\
\hline X \& Y Steer & $10 \mathrm{~V}, 10 \mathrm{~A}$ \\
\hline VACUUM PUMPING SPECIFICATIONS \\
\hline Turbo Pumps, 2X \\
Upstream \& Downstream
\end{tabular}




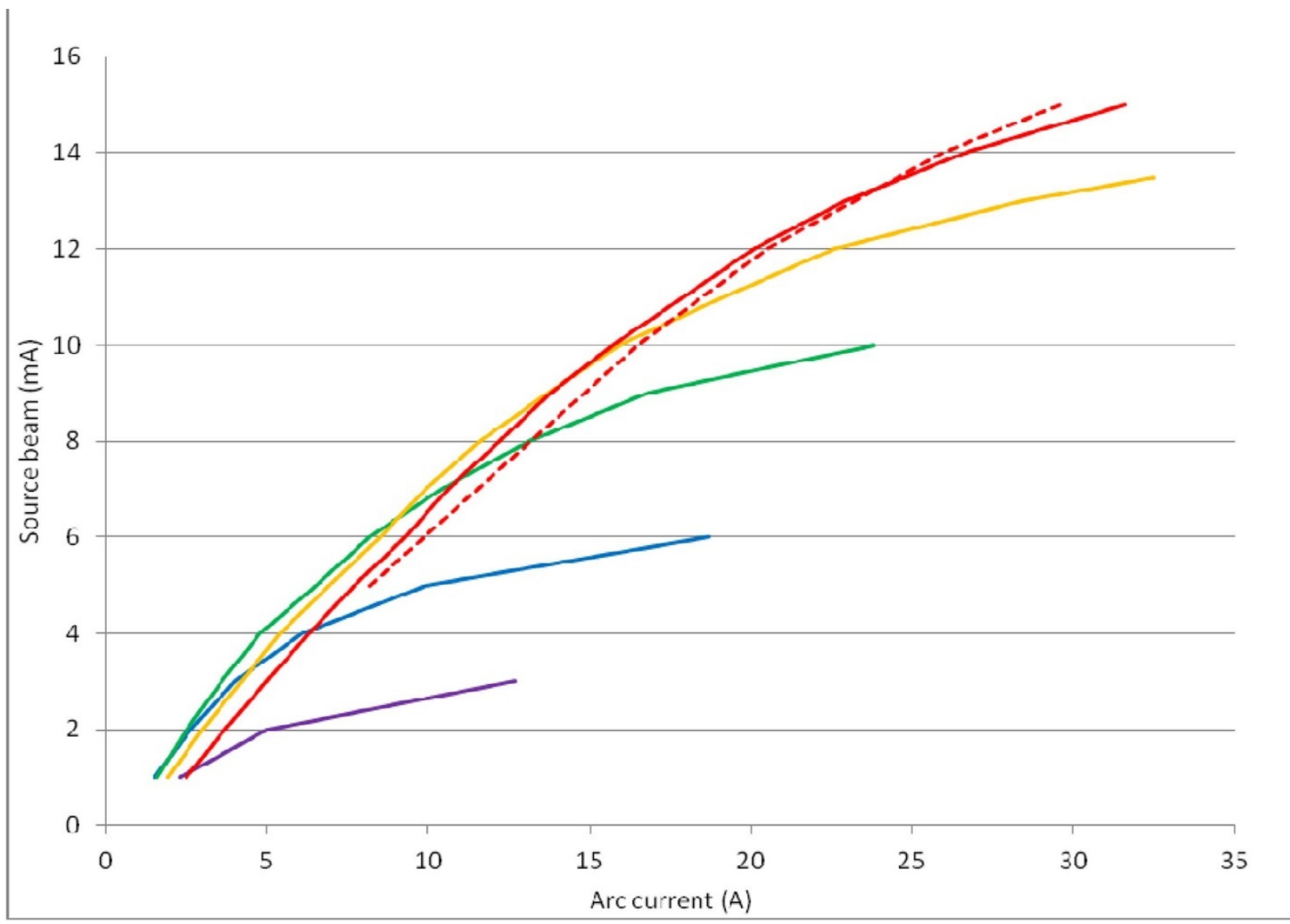

$\begin{array}{lcl}\text { Purple } & : & 3 \mathrm{sccm} \\ \text { Blue } & : & 6 \mathrm{sccm} \\ \text { Green } & : & 9 \mathrm{sccm} \\ \text { Yellow } & : & 12 \mathrm{sccm} \\ \text { Red } & 15 \mathrm{sccm} \\ \text { Red (dashed line) } & 18 \mathrm{sccm}\end{array}$

Fig. 4. The extracted $\mathrm{H}^{-}$beam current as a function of $\mathrm{H}_{2}$ gas feed rate and filament arc current for the baseline D-Pace $15 \mathrm{~mA}$ source. Courtesy of D-Pace, Inc.

Table IV. Typical source parameters during a startup as the arc current is brought up to full operating conditions. Courtesy of D-Pace, Inc. 
Sample Tune Data:

\begin{tabular}{|c|c|c|c|c|c|c|c|c|c|c|c|c|c|c|}
\hline $\begin{array}{c}\text { Beam } \\
\text { Current } \\
\mathrm{H}^{-} \\
(\mathrm{mA})\end{array}$ & $\begin{array}{c}\text { Bias } \\
\text { Supply } \\
\text { (mA, kV) }\end{array}$ & $\begin{array}{c}\text { Arc } \\
\text { Supply } \\
(A, V)\end{array}$ & $\begin{array}{c}\text { Filament } \\
\text { Supply } \\
(\mathrm{A}, \mathrm{V})\end{array}$ & $\begin{array}{c}\text { Plasma } \\
\text { Lens } \\
\text { Supply } \\
(\mathrm{A}, \mathrm{V})\end{array}$ & $\begin{array}{l}\text { Extraction } \\
\text { Lens Supply } \\
\text { (mA, kV) }\end{array}$ & $\begin{array}{c}\text { Steering } \\
\text { Magnet } \\
\mathbf{X} \\
(\mathrm{A}, \mathrm{V})\end{array}$ & $\begin{array}{c}\text { Steering } \\
\text { Magnet } \\
Y \\
(A, V)\end{array}$ & $\begin{array}{c}\mathrm{H}_{2} \\
\text { (sccm) }\end{array}$ & $\begin{array}{c}\text { Vacuum, } \\
\text { Ion Source } \\
\text { (Upstream) } \\
\text { (Torr) }\end{array}$ & $\begin{array}{c}\text { Vacuum, } \\
\text { V-Box } \\
\text { (Downstream) } \\
\text { (Torr) }\end{array}$ & $\begin{array}{c}1 / 2 \text { Beam } \\
\text { Diameter } \\
\text { at Waist } \\
(\mathrm{mm})\end{array}$ & $\begin{array}{c}1 / 2 \text { Beam } \\
\text { Divergence } \\
\text { at Waist } \\
\text { (mrad) }\end{array}$ & $\begin{array}{l}\text { Geometric } \\
\text { 4rms } \\
\text { Emittance } \\
\text { (mm } \cdot \mathrm{mrad})\end{array}$ & $\begin{array}{c}\text { Normalized } \\
\text { 4rms } \\
\text { Emittance } \\
\text { (mm·mrad) }\end{array}$ \\
\hline 5.0 & $\begin{array}{c}7.1 \\
30\end{array}$ & $\begin{array}{l}8.8 \\
120\end{array}$ & $\begin{array}{l}231, \\
3.43\end{array}$ & $\begin{array}{l}4.2 \\
3.23\end{array}$ & $\begin{array}{l}26.2 \\
2.12\end{array}$ & 0.00 & 0.00 & 10 & $3.59 \mathrm{e}-5$ & $2.62 \mathrm{e}-6$ & 2.01 & 45.4 & 91 & 0.73 \\
\hline 10.0 & $\begin{array}{c}13.5 \\
30\end{array}$ & $\begin{array}{c}18.8 \\
120\end{array}$ & $\begin{array}{l}204, \\
3.15\end{array}$ & $\begin{array}{l}9.36 \\
3.99\end{array}$ & $\begin{array}{l}33.9, \\
2.99\end{array}$ & 5.00 & 3.00 & 13 & $3.21 \mathrm{e}-5$ & $3.52 \mathrm{e}-6$ & 1.69 & 40.1 & 68 & 0.54 \\
\hline 13.0 & $\begin{array}{c}17.9 \\
30\end{array}$ & $\begin{array}{c}26.8, \\
120\end{array}$ & $\begin{array}{l}176 \\
2.74\end{array}$ & $\begin{array}{l}12.5, \\
3.82\end{array}$ & $\begin{array}{l}60.8 \\
3.45\end{array}$ & 1.00 & 1.64 & 15 & $4.65 e-5$ & $4.56 \mathrm{e}-6$ & 2.21 & 41.05 & 91 & 0.73 \\
\hline 15.0 & $\begin{array}{c}20.4 \\
30\end{array}$ & $\begin{array}{c}33.6 \\
120\end{array}$ & $\begin{array}{l}143, \\
2.34\end{array}$ & $\begin{array}{l}15.8 \\
3.94\end{array}$ & $\begin{array}{l}71.2 \\
3.56\end{array}$ & 0.82 & 1.55 & 17 & $5.00 e-5$ & $5.19 \mathrm{e}-6$ & 2.52 & 34.7 & 87 & 0.70 \\
\hline 18.0 & $\begin{array}{c}24.9, \\
30\end{array}$ & $\begin{array}{c}47.5 \\
120\end{array}$ & $\begin{array}{c}35, \\
0.89\end{array}$ & $\begin{array}{l}21.2, \\
3.83\end{array}$ & $\begin{array}{l}127, \\
3.80\end{array}$ & 0.82 & 1.55 & 20 & $4.65 e-5$ & $6.24 \mathrm{e}-6$ & 2.72 & 34.4 & 94 & 0.75 \\
\hline
\end{tabular}

\section{C.) Phase Space Analysis System 2.0

\begin{tabular}{|l|l|l|}
\hline \multicolumn{1}{|l|}{ File Name } \\
\hline 15 mA_beam_scan \\
\hline Scan \\
\hline Date: & $12 / 1 / 2016$ \\
\hline Time: & $3: 43: 12 \mathrm{PM}$ \\
\hline Beam Energy: & $30 \mathrm{keV}$ \\
\hline \# y & 81 points \\
\hline delta y & $0.5 \mathrm{~mm}$ \\
\hline \# $\mathrm{y}^{\prime}$ & 121 points \\
\hline delta $\mathrm{y}^{\prime}$ & $1 \mathrm{mrad}$ \\
\hline Axis: & Vertical Top \\
\hline Rejection Threshold \\
\hline $4 \%$ & Emittance Mode \\
\hline Beam Centroid \\
\hline$y$ & $0.733325 \mathrm{~mm}$ \\
\hline$y^{\prime}$ & $0.195592 \mathrm{mrad}$ \\
\hline TWISS Parameters \\
\hline$\beta$ & $1.561007 \mathrm{~mm} / \mathrm{mrad}$ \\
\hline$\gamma$ & $13.774197 \mathrm{mrad} / \mathrm{mm}$ \\
\hline$\alpha$ & -4.527871 \\
\hline Beam Waist Location \\
\hline$\Delta z$ & $-0.328721 \mathrm{~m}$ \\
\hline
\end{tabular}

Ellipse Phase Space Area $=\pi \varepsilon$

$t \cdot \varepsilon_{r m s(\text { waist })}=\left(2 \cdot y_{w r m s}\right) \cdot\left(2 \cdot y_{r m s}^{\prime}\right)$

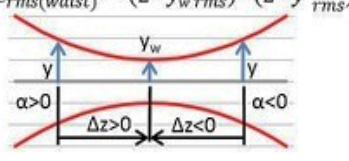

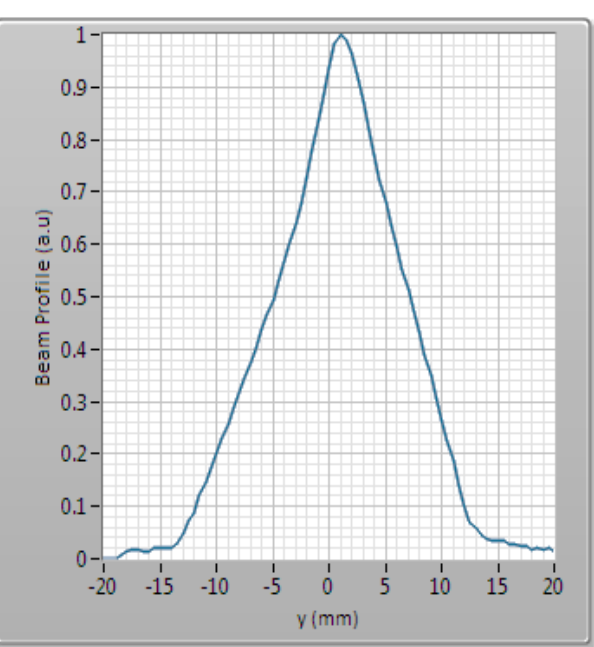

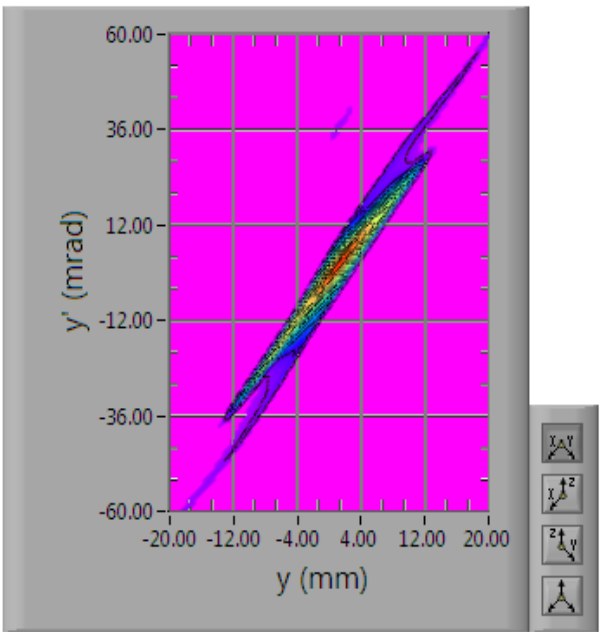

\begin{tabular}{|c|c|c|c|c|c|c|c|c|c|}
\hline \multicolumn{2}{|c|}{ \% Beam In Ellipse } & \multicolumn{3}{|c|}{ \% Beam Dimensions } & \multicolumn{2}{|c|}{ Emittance } & \multicolumn{3}{|c|}{ Transport Sigma Matrix } \\
\hline$\%$ & $\begin{array}{c}n \\
n \cdot \varepsilon_{r m s}\end{array}$ & $\underset{(\mathrm{mm})}{\mathbf{Y}}$ & $\begin{array}{c}\mathbf{Y w}_{\mathrm{w}} \\
\text { Waist } \\
(\mathrm{mm})\end{array}$ & $\underset{\text { (mrad) }}{\mathbf{y}^{\prime}}$ & $\begin{array}{c}\mathcal{E}_{\mathrm{N}} \\
\text { Normalized } \\
(\mathrm{mm} \bullet \mathrm{mrad})\end{array}$ & $\begin{array}{c}\mathcal{E} \\
\text { Geometric } \\
(\mathrm{mm} \bullet \mathrm{mrad})\end{array}$ & $\underset{\left(m m^{\wedge} 2\right)}{\sigma_{11}}$ & $\begin{array}{l}\sigma_{12}=\sigma_{21} \\
(\mathrm{~mm} * \mathrm{mrad})\end{array}$ & $\underset{\left(\operatorname{mrad}_{22} 2\right)}{\sigma_{22}}$ \\
\hline 42.8825 & 1 & 5.8365 & 1.2587 & 17.3373 & 0.1745 & 21.8222 & 34.0646 & 98.8082 & 300.5836 \\
\hline 67.3200 & 2 & 8.2540 & 1.7800 & 24.5187 & 0.3491 & 43.6444 & 68.1293 & 197.6164 & 601.1672 \\
\hline 81.6787 & 3 & 10.1091 & 2.1801 & 30.0292 & 0.5236 & 65.4667 & 102.1939 & 296.4246 & 901.7508 \\
\hline 89.4053 & 4 & 11.6730 & 2.5174 & 34.6747 & 0.6981 & 87.2889 & 136.2585 & 395.2328 & 1202.3344 \\
\hline 93.3160 & 5 & 13.0508 & 2.8145 & 38.7675 & 0.8727 & 109.1111 & 170.3232 & 494.0410 & 1502.9181 \\
\hline 95.6906 & 6 & 14.2964 & 3.0831 & 42.4677 & 1.0472 & 130.9333 & 204.3878 & 592.8492 & 1803.5017 \\
\hline 97.8075 & 8 & 16.5081 & 3.5601 & 49.0374 & 1.3963 & 174.5778 & 272.5171 & 790.4656 & 2404.6689 \\
\hline 98.8992 & 10 & 18.4566 & 3.9803 & 54.8255 & 1.7453 & 218.2222 & 340.6463 & 988.0820 & 3005.8361 \\
\hline
\end{tabular}

Fig. 5. A typical emittance measurement data set from taken from the D-Pace test stand for the baseline D-Pace ion source. Courtesy of D-Pace, Inc. 


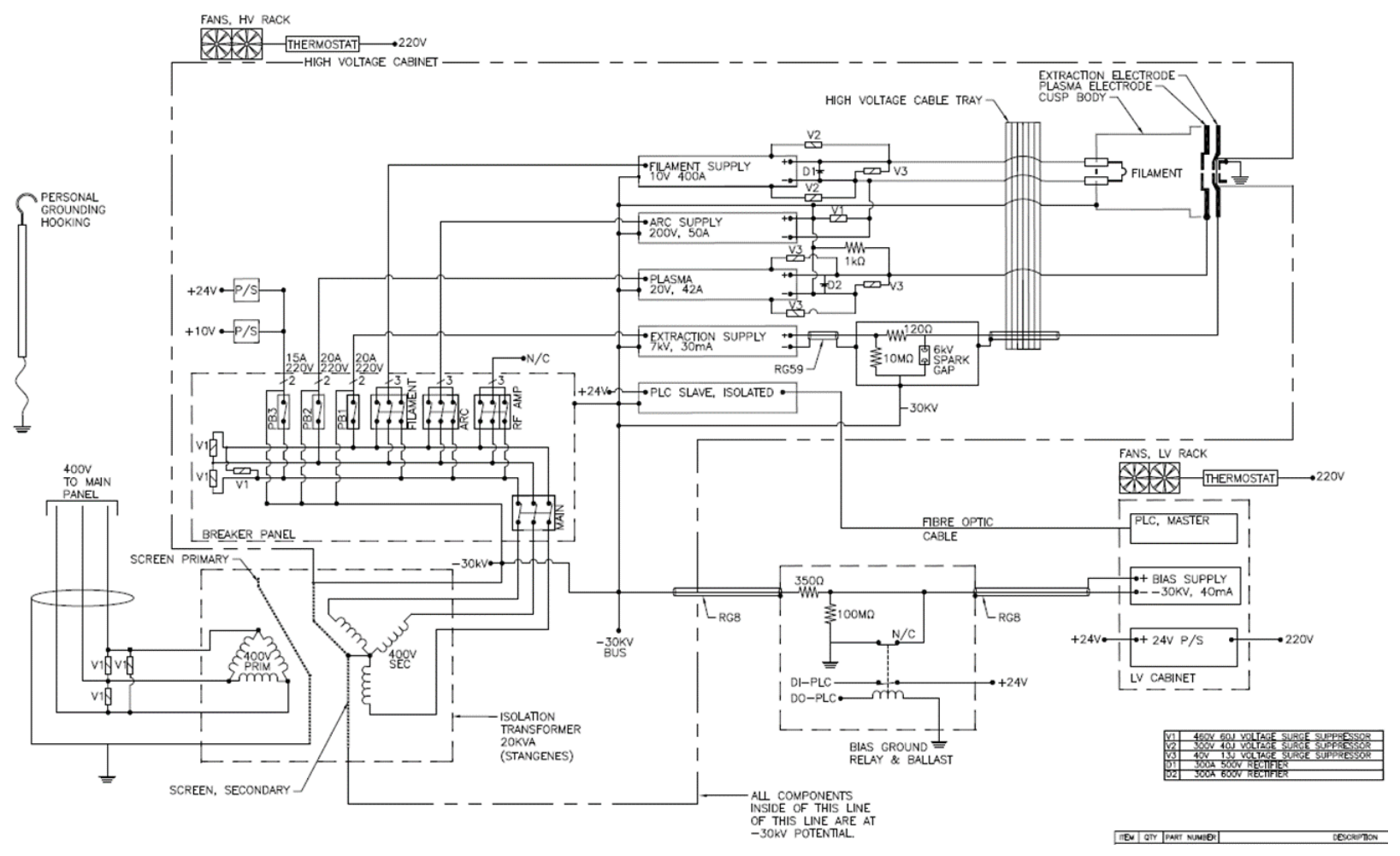

Fig. 6. Electrical diagram for a typical installation of a D-Pace source. Courtesy of D-Pace, Inc.

\section{TRIUMF PROOF-OF-PRINCIPLE $60 \mathrm{~mA}$ STEADY-STATE EXPERIMENT}

In 2018 the TRIUMF ion source team performed and experiment in which a variant of the baseline D-Pace source was equipped with a larger array of four helical W filaments $(\phi=2.5 \mathrm{~mm})$, larger power supplies (filament: $10 \mathrm{~kW}$; Arc: $15 \mathrm{~kW})$ and a larger outlet aperture $(\phi=19 \mathrm{~mm})$ [24]. The filament configuration, shown in Fig. 7, features pairs of counter wound coils to reduce the magnetic field associated with the filament current in the plasma. A cross sectional view of the source and experimental test chamber used in the experiment is also shown in Fig. 7. Fig. 8 shows a simplified electrical schematic of the upgraded power supply configuration featuring a larger filament power supply (10V 1000A) and the plasma arc supply $(150 \mathrm{~V}, 100 \mathrm{~A})$. Overall, this new configuration requires $\sim 50 \mathrm{kVA}$ of electrical service.

It was found that a plasma could be ignited with $800 \mathrm{~A}$ of filament current which was reduced to $400 \mathrm{~A}$ when the plasma arc was established with $90 \mathrm{~A}$ of arc current and $140 \mathrm{~V}$ arc voltage. Under these conditions the TRIUMF team demonstrated that $\mathrm{DC} \mathrm{H}^{-}$beams of up to $60 \mathrm{~mA}$ could be extracted from the source. Moreover they noted a linear increase in beam current up to $50 \mathrm{~mA}$ with increasing arc power, See Fig. 9. A private communication with the team revealed that the experiment only ran for a brief period and was intended to be just as a proof-of-principle test and would require significant development to design an stable source working at this beam current. They cited the large outlet aperture $(\phi=19 \mathrm{~mm})$ and the melting of the extraction electrodes are issues which will need to be overcome if the source was to be used to inject an operational accelerator. We have been unable to simulate any acceptable beam emittance solutions using such a large extraction aperture (see section $5 b)$. 


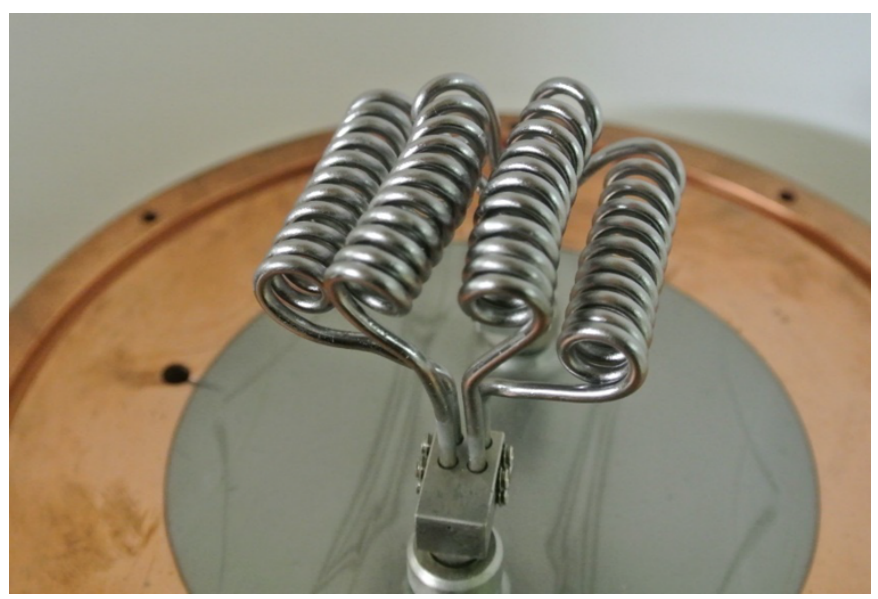

(a)

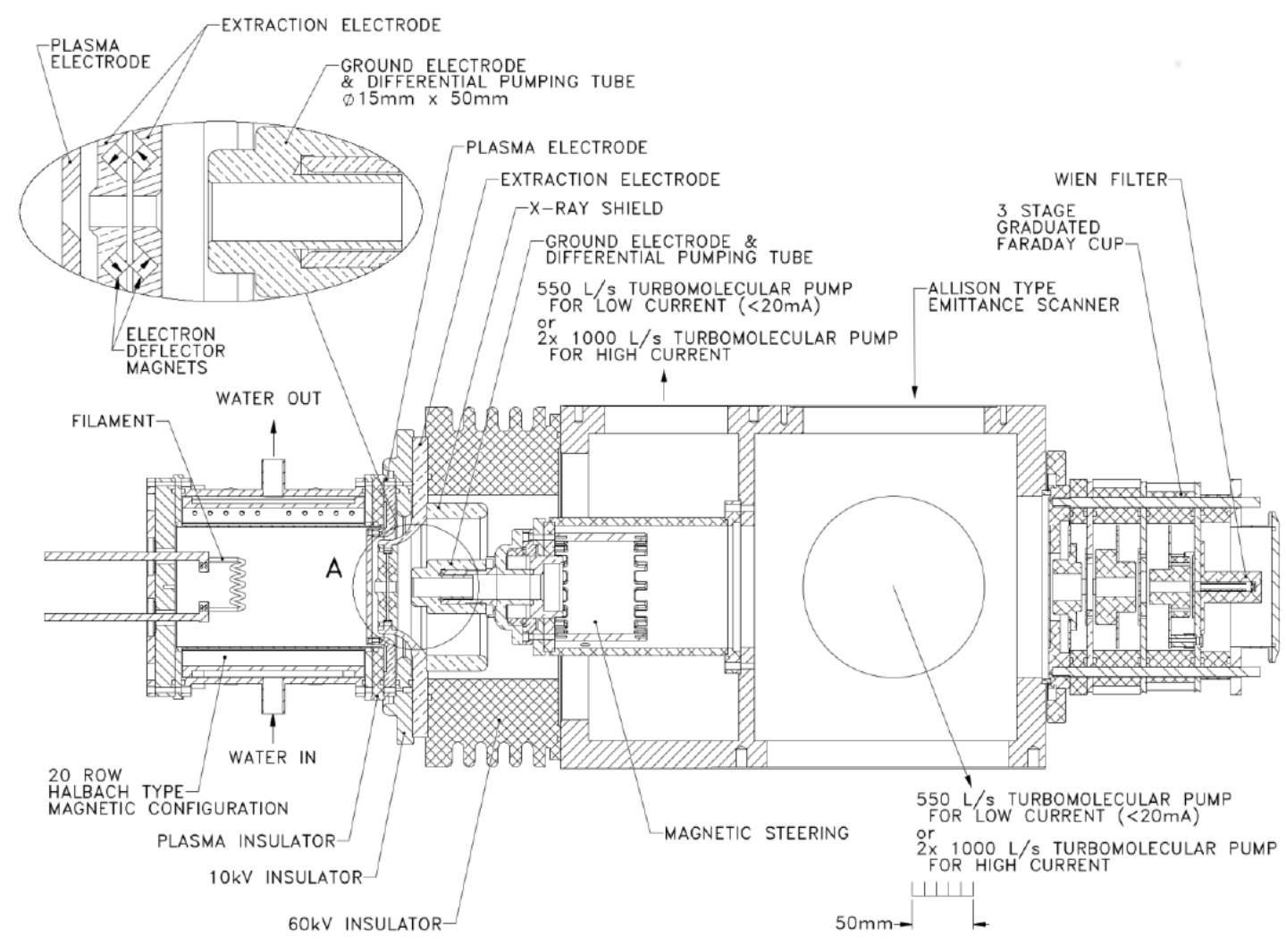

(b)

Fig. 7 (a) TRIUMF high-current filament array and (b) Cross sectional view of the TRIUMF $60 \mathrm{~mA}$ proof-of-principle experimental ion source and test chamber. Courtesy K. Jayamanna. 


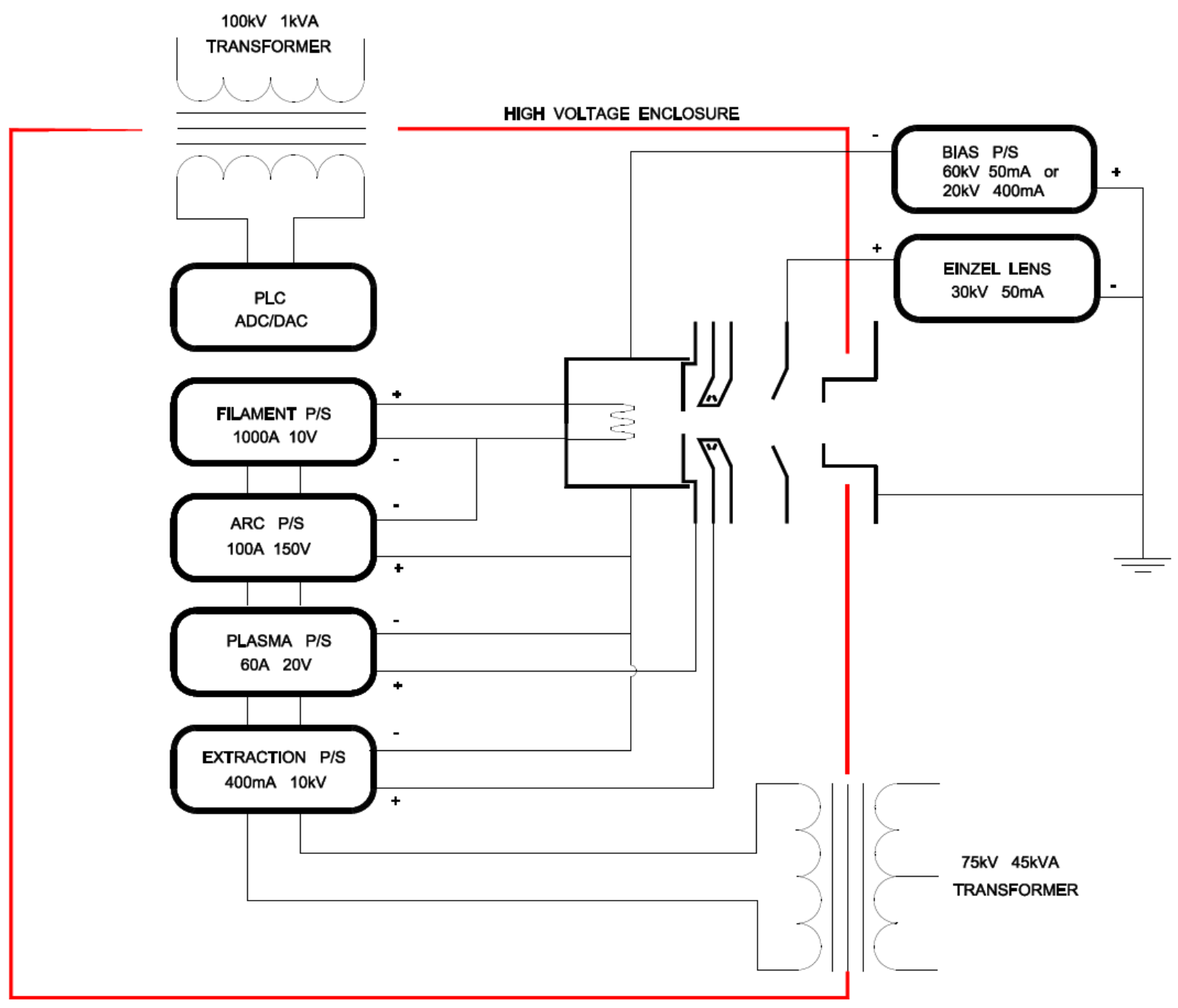

Fig. 8. A simplified electrical diagram of the power supply configuration used in the TRIUMF $60 \mathrm{~mA}$ proof-of-principle test. Courtesy K. Jayamanna. 


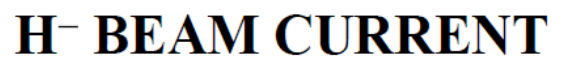

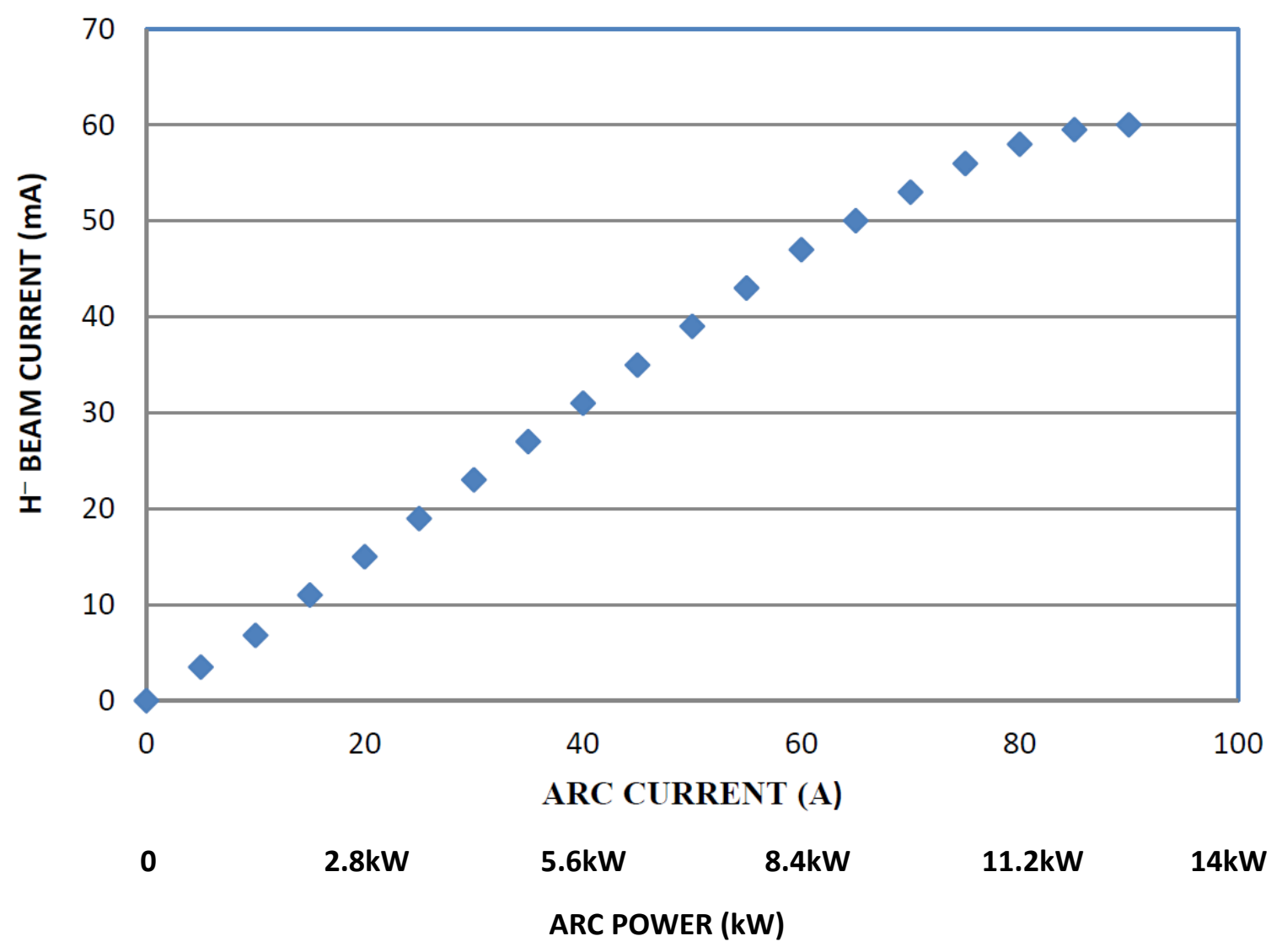

Fig. 9. The $\mathrm{H}^{-}$beam current extracted with increasing arc current during the TRIUMF $60 \mathrm{~mA}$ proof-ofprinciple test through a $\phi=19 \mathrm{~mm}$ extraction aperture. The arc voltage was fixed at $140 \mathrm{~V}$. Courtesy K. Jayamanna.

\section{SUMITOMO CESIATION TEST OF THE D-PACE SOURCE}

In 2013 the ion source team from Sumitomo Heavy Industries added a Cs reservoir to a modified D-Pace $15 \mathrm{~mA} \mathrm{H}^{-}$ion source, using the standard $13 \mathrm{~mm}$ outlet aperture [18]. The found that both the $\mathrm{H}_{2}$ consumption rate could be reduced and the $\mathrm{H}^{-}$beam current output was significantly increased. Fig. 10 shows schematic cross-sectional view of the source and the location of the Cs-injection port. The figure also shows the relative performance of the source for Cs-seeded and uncesiated cases. These data show that approximately a $1.5 \mathrm{x}$ improvement in $\mathrm{H}^{-}$output could be realized thereby increasing the source efficiency to $\sim 5 \mathrm{~mA}$ per $\mathrm{kW}$ of arc power from a $13 \mathrm{~mm}$ outlet aperture. One should note that no data exists for the Cs consumption rate in this source but such estimates maybe made from the LANL filament ion source [25]. 


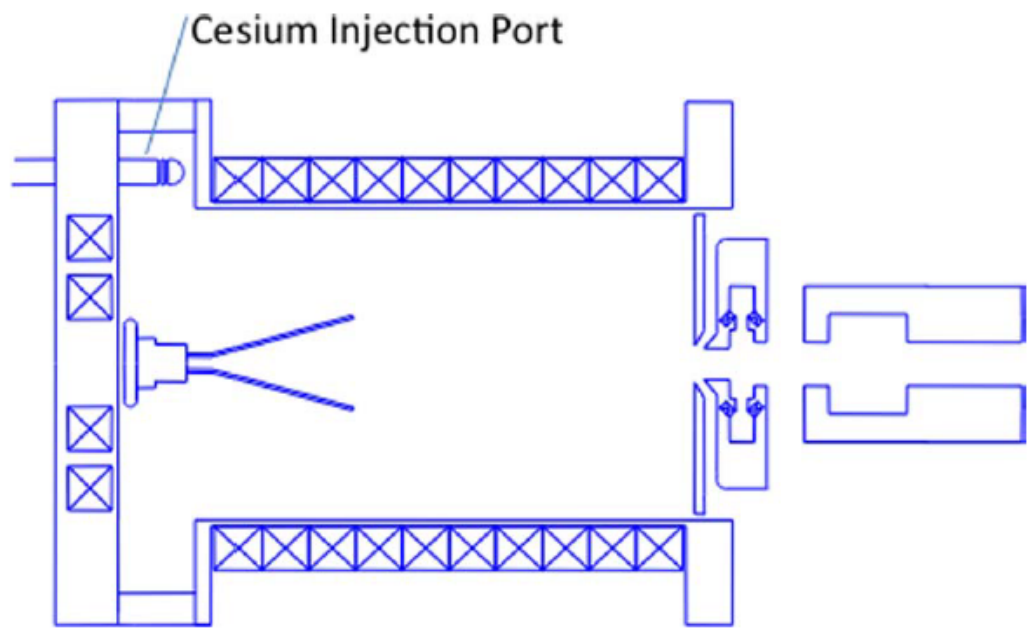

(a)

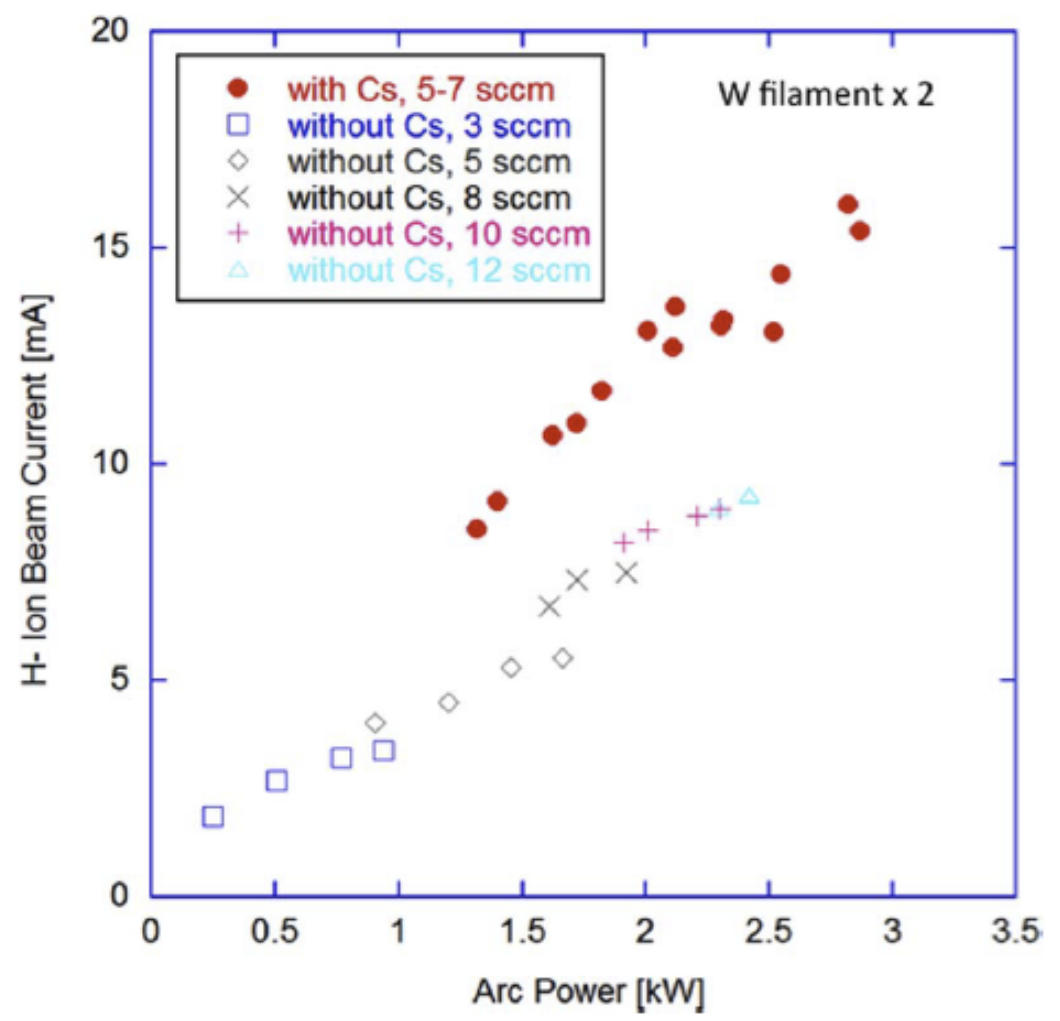

(b)

Fig. 10. (a) Schematic cross sectional view of the ion source used in the Sumitomo cesiation experiment. (b) Ion source performance and $\mathrm{H}_{2}$ gas consumption for source operation with and without Cesium injection. Courtesy of Sumitomo Heavy Industries Ltd. 


\section{DEVELOPMENT PATH TOWARDS AN OPERATIONAL $>15$ mA DC H- ION SOURCE}

As noted in section 4, if a D-Pace-type ion source is retrofitted with a larger array of filaments and more powerful arc and filament power supplies are employed, the extracted $\mathrm{H}^{-}$current does increase linearly with increasing arc power to $\sim 11 \mathrm{~kW}$, as seen in Fig. 9. Although this experiment was performed using a $\phi=19$ mm plasma outlet aperture, the observed $\mathrm{H}^{-}$beam current linearity should hold for smaller outlet aperture sizes like $\phi=13 \mathrm{~mm}$, which are well suited for this project. In section 4 , we learned that the introduction of Cs into a D-Pace type source enhances the $\mathrm{H}^{-}$production efficiency to approximately $5 \mathrm{~mA} / \mathrm{kW}$ of arc power through a nominal $\phi=13 \mathrm{~mm}$ aperture in the arc power range of $0-3 \mathrm{~kW}$. Thus, if this scaling holds, as shown in Fig. 9, it should be possible to extract a DC $\mathrm{H}^{-}$beam current of $\sim 50 \mathrm{~mA}$ using $\sim 10 \mathrm{~kW}$ of arc power and Cs-injection from modified D-Pace source. We should also note that this level of Csenhancement is also observed in RF-driven, multicusp $\mathrm{H}^{-}$ion sources operating with discharge powers of $\sim 50 \mathrm{~kW}[10]$. In the next sections we will use plasma, ion optical, mechanical and electrical simulations and calculations to explore the feasibility and limitations of modifying a D-Pace source to support longterm, stable operation under these conditions.

In section 5.1 we will estimate the expected emittance growth at these higher beam currents which could be extracted from such a modified D-Pace ion source. In section 5.2, we will model the higher plasma heat loads on the internal structures of the ion source to insure proper long-term thermal management can be achieved for this level of arc power. Lastly, in section 5.3 we will discuss the electrical requirements of realizing such a source configuration as well as methods to convert a high-intensity, steady-state $\mathrm{H}^{-}$ion source to operate in the pulsed regime which is also a requirement of the LANL NPB project.

\subsection{Beam Extraction Simulations}

PBGUNS is widely used to model positive and negative ion beam extraction from plasma ion sources in 2dimensions by iteratively solving the Poisson equation accounting for the space charge of the extracted ions and electrode voltage boundary conditions [26, 27]. It also finds a self-consistent solution for the shape and location of the plasma meniscus or the beam-plasma boundary. The resulting ion beam trajectories are then modelled through the extraction system subject to their repulsive space charge forces and are statistically analyzed at specified emittance analysis planes.

In this report we first compare beam extraction simulations of the conventional D-Pace ion source with experimental measured data [23]. Both simulation and experiment were performed using the baseline DPace ion source and extraction system shown in Fig.11a operating under nominal conditions: $15 \mathrm{~mA}^{-} \mathrm{H}^{-}$ current at $30 \mathrm{kV}$ of beam energy. As evidenced in Fig. 12, the measured and simulated rms emittance values were found to be in good agreement although the overall ellipse is somewhat distorted from the measurement but in the correct orientation. Both data sets were thresholded at $4.5 \%$.

Next, we employed PBGUNS to validate the use of this extraction system (or minor variations) for higher beam currents and energies relevant to the LANL NPB project. Beam energy: 30-75kV; Beam current: $15-$ $100 \mathrm{~mA}$. Since the specific acceptance of the LANL project is not yet known we focused on solutions with normalized, 1-RMS emittance $<0.3 \pi \mathrm{mm}$ mrad to allow efficient injection into a conventional RFQ, like the SNS RFQ [28]. 


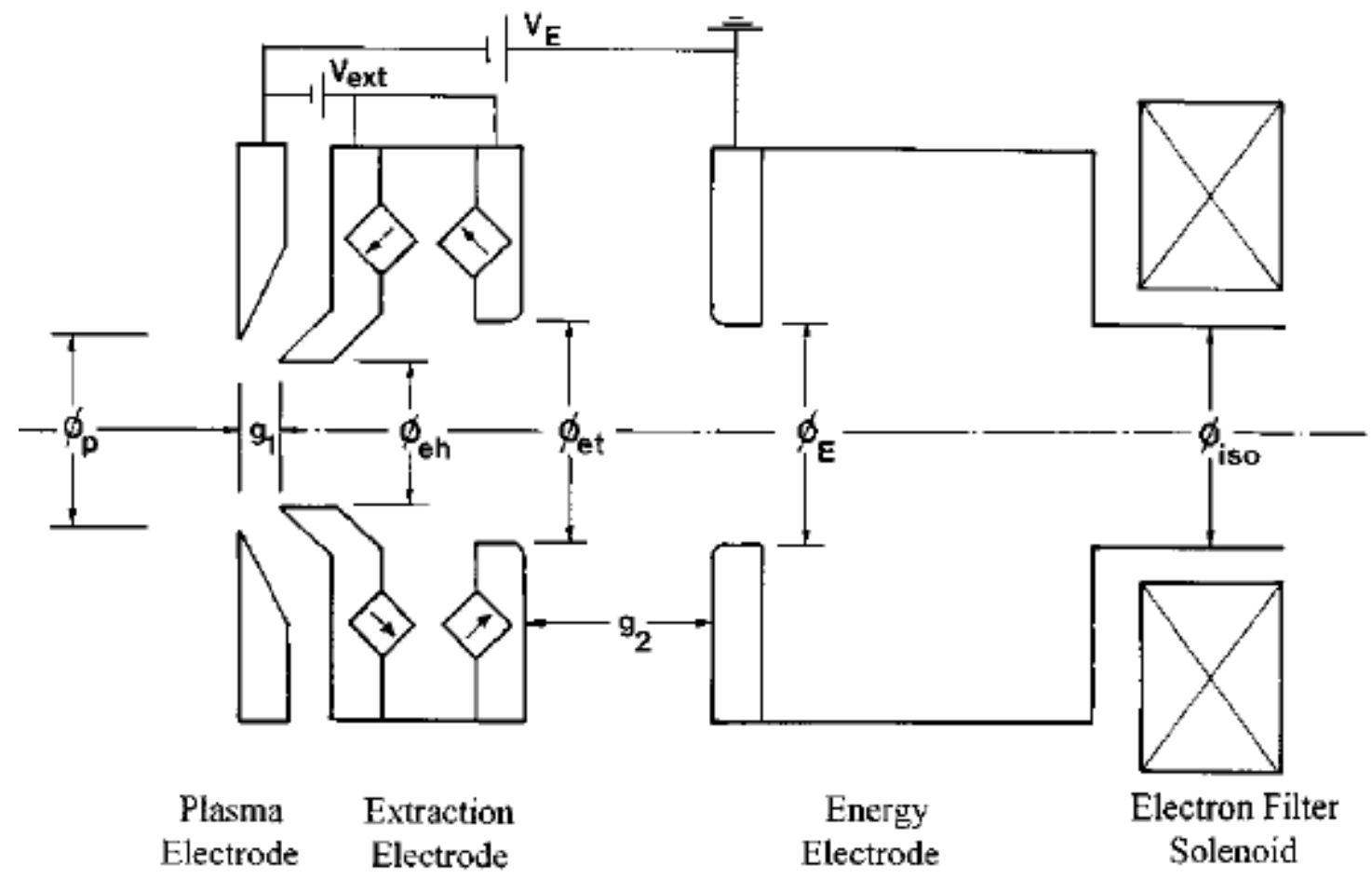

For a $17.5 \mathrm{~mA}$ DC $\mathrm{H}^{-}$extraction: $\mathrm{g}_{1}=2.5 \mathrm{~mm}, \mathrm{~g}_{2}=10 \mathrm{~mm}$, $\mathrm{V}_{\mathrm{E}}=28 \mathrm{KV}, \mathrm{V}_{\mathrm{exi}}=3.8 \mathrm{KV}$, $\emptyset_{\mathrm{p}}=13.0 \mathrm{~mm}, \emptyset_{\mathrm{eh}}=9.5 \mathrm{~mm}$, $\emptyset_{\mathrm{et}}=\emptyset_{\mathrm{E}}=\emptyset_{\text {iso }}=14.0 \mathrm{~mm}$,

(a)

\section{TRAJECTORIES AND EQUIPOTENTIALS}

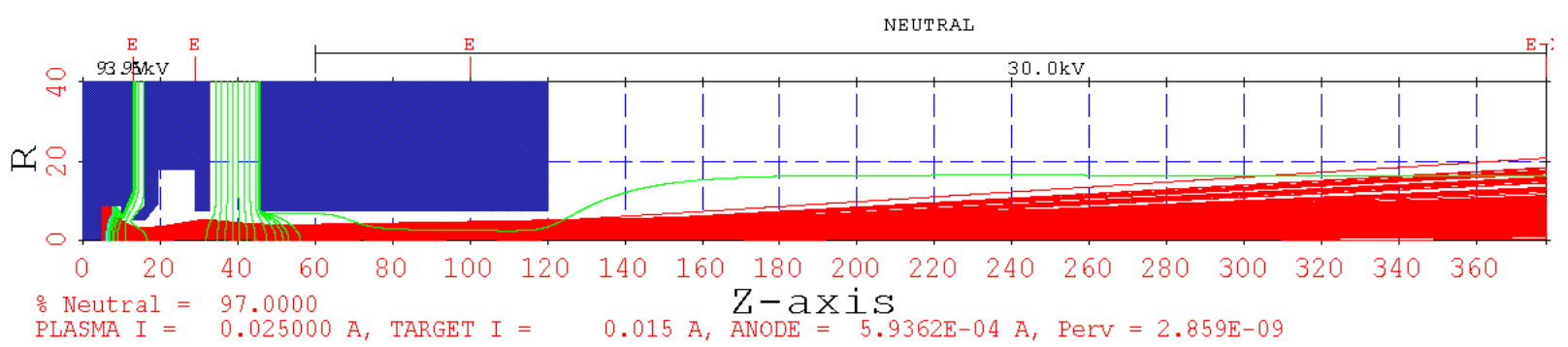

(b)

Fig. 11. (a) The conventional extraction system widely used in D-Pace source installations [13]. (b) Cross sectional view of the modelled extraction system showing the beam trajectories and equipotentials. Emittance was analyzed at $\mathrm{z}=380 \mathrm{~mm}$. 


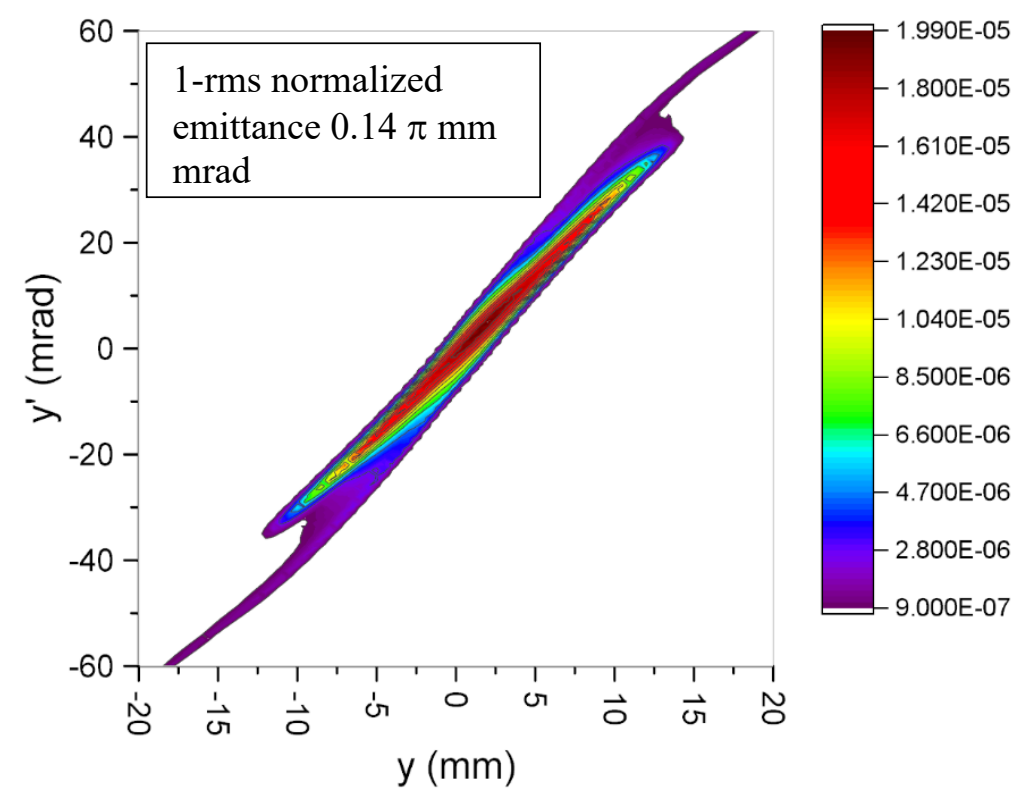

(a)

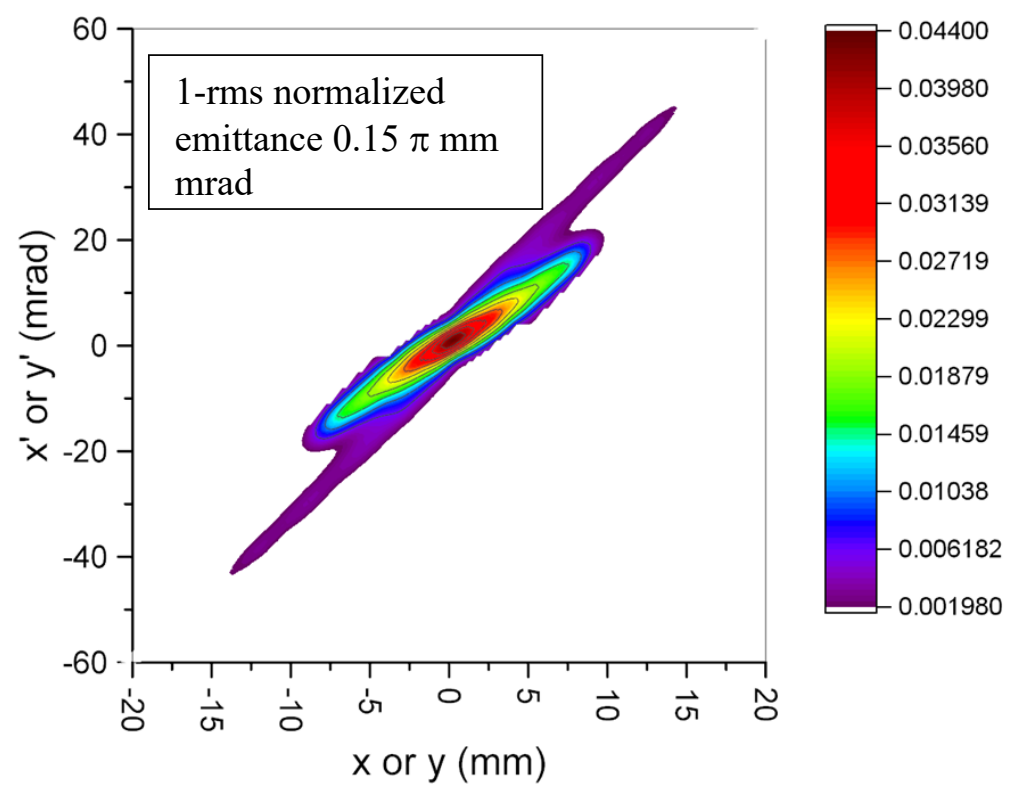

(b)

Fig. 12. (a) Measured vertical transverse emittance from the D-Pace ion source $(15 \mathrm{~mA}, 30 \mathrm{kV})$. (b) Simulated transverse emittance from the D-Pace source $(15 \mathrm{~mA}, 30 \mathrm{kV})$. Both data sets have been thresholded at $4.5 \%$. 
Table V shows a summary of these studies. The normalized 1-RMS emittance was calculated for the DPace extraction system under conditions higher extraction voltages and beam currents. Geometry shown in Fig. 11a was adjusted slightly to accommodate higher beam currents but the outlet aperture was fixed at $\phi=13 \mathrm{~mm}$. Outlet aperture diameters $>14 \mathrm{~mm}$ were not considered as they generally yielded too high emittance in our simulations. No methodical optimization of geometry was performed instead we showed some possible converged solutions and the expected emittance. Table V shows that beams of $\sim 60 \mathrm{~mA}$ can be extracted from a $\phi=13 \mathrm{~mm}$ outlet aperture using a D-Pace type extraction geometry with acceptable emittance. In the final design the extract electrode will likely require direct water cooling to deal with the dumping of $\sim 3 \mathrm{x}$ more electron flux - this will be a key area of focus during the next stages of the project. We were not able to find solutions for $100 \mathrm{~mA}$ extracted through a $\phi=13 \mathrm{~mm}$ outlet aperture with acceptable emittances at this time. In the next project phase we will focus the design of an extraction system matched to the specific acceptance phase space of the LANL NPB RFQ.

Table V. Summary of simulated 1-rms emittance values from the conventional D-Pace extraction system shown in Fig. 11a.

\begin{tabular}{|c|c|c|c|c|}
\hline & & & & \\
\hline & RMS Emittances & $30 \mathrm{kV}$ & $55 \mathrm{kV}$ & $75 \mathrm{kV}$ \\
\hline & $15 \mathrm{~mA}$ & 0.15 & 0.18 & 0.14 \\
\hline E⿱ & $30 \mathrm{~mA}$ & 0.24 & 0.33 & 0.30 \\
\hline ラ & $60 \mathrm{~mA}$ & 0.37 & 0.28 & 0.28 \\
\hline & $100 \mathrm{~mA}$ & - & - & 0.44 \\
\hline
\end{tabular}

\subsection{Mechanical Considerations}

In this section we will model the increased thermal loads imposed on ion source structures due to operation of the source at the elevated filament and arc power levels discussed above. This study will primarily utilize the finite element analysis suite ANSYS due to its ability to perform coupled thermal, mechanical, fluid and radiative modelling [29]. In section 5.2.1, we will first perform a plasma physics analysis to estimate the heat flux generated by the discharge that will be transferred to the ion source structures: plasma chamber and filament array. In 5.2.2 we will use ANSYS and analytical methods to model the plasma chamber wall temperature and required water cooling flow needed to manage the surface heat loads calculated above. In 5.2.3 we will again use ANSYS to model the radiative cooling properties of the filament array to insure stable operation with the increased plasma heat load. We will then use filament lifetime models developed at LANL to estimate their lifetime under these high arc power conditions.

\subsubsection{Estimate of the heat load generated by the ion source plasma}

Here we estimate the plasma energy balance of the ion source under conditions of the TRIUMF experiment. The plasma is heated by the arc current emitted from the tungsten filament, we will use the following parameters of the source. Plasma: $\mathrm{n}_{\mathrm{e}} \sim 1.5 \cdot 10^{12} \mathrm{~cm}^{-3}$ (electron density); $\mathrm{T}_{\mathrm{e}} \sim 2 \mathrm{eV}$ (electron temperature); chamber is cylindrical having $5 \mathrm{~cm}$ radius and $15 \mathrm{~cm}$ length; $\mathrm{V}_{\mathrm{a}} \sim 140 \mathrm{~V}$ arc voltage, $\mathrm{I}_{\mathrm{a}} \sim 90 \mathrm{~A}$ arc current. 
Filament: 4 identical $\mathrm{W}$ filaments with $\mathrm{d}=2.5 \mathrm{~mm}$ diameter and $\mathrm{L}=29.5 \mathrm{~mm}$ length. Filament current is up to $\mathrm{I}=200 \mathrm{~A}$ per filament, DC voltage drop is $\mathrm{V} \sim 8.7 \mathrm{~V}$.

The DC power generated by current through each filament is roughly $\mathrm{P}_{\mathrm{DC}} \sim \mathrm{I} \cdot \mathrm{V} \sim 1.7 \mathrm{~kW}$. This estimate does not take into account the nonuniform distribution of current and temperature along the filament. Ion heating is caused by the ions from plasma which are accelerated by the sheath located next to the filament-plasma boundary. Each ion has the energy of $140 \mathrm{eV}$. The ion current can be estimate as the Bohm current, $\mathrm{I}_{\mathrm{i}} \sim 0.6 \cdot \mathrm{e} \cdot \mathrm{n}_{\mathrm{e}} \cdot\left(\mathrm{T}_{\mathrm{e}} / \mathrm{m}_{\mathrm{i}}\right)^{1 / 2} \cdot(\pi \mathrm{dL}) \sim 5 \mathrm{~A}$ per each filament [30] (as a result, the electron arc current is $\left.\mathrm{I}_{\mathrm{e}} \sim \mathrm{I}_{\mathrm{a}}-4 \mathrm{I}_{\mathrm{i}} \sim 70 \mathrm{~A}\right)$. Then the power deposited from plasma to the filament by the ion current is $\mathrm{P}_{\mathrm{i}} \sim \mathrm{I}_{\mathrm{i}} \cdot \mathrm{V}_{\mathrm{a}} \sim \mathbf{7 0 0 \mathrm { W }}$ per filament. Electron cooling is caused by the need of electro to transition from the metal into plasma and overcome the work function. This effect causes cooling of the filament. The power of electron cooling is $\mathrm{P}_{\mathrm{e}} \sim \mathrm{I}_{\mathrm{e}} / 4 * 4.5 \mathrm{~V} \sim \mathbf{8 0} \mathrm{W}$ per filament [30].

Another channel for power transfer includes heating of the filament by the neutral in plasma. This channel of the energy transfer has not been included in the past models. We assume that all the species in plasma (electrons, ions and neutrals) have the same temperature. This assumption is valid in a DC regime of the ion source when all the species in plasma thermalize on some time scale. The flux of neutrals to filament can be estimated as $\mathrm{dN} / \mathrm{dt}=\mathrm{n}_{\mathrm{H} 2}<\mathrm{V}_{Z}>\cdot(\pi \mathrm{dL})$, where $\mathrm{n}_{\mathrm{H} 2}$ is the density of $\mathrm{H}_{2}$ neutrals in partially ionized plasma. We assume that the plasma is $\sim 1 \%$ ionized, which results in $\mathrm{n}_{\mathrm{H} 2} \sim 1.5 \cdot 10^{14} \mathrm{~cm}^{-3} .<\mathrm{V}_{\mathrm{Z}}>$ is the average velocity of neutrals across some virtual plane inside plasma and can be estimate as $\left\langle\mathrm{v}_{\mathrm{Z}}\right\rangle=\left(\mathrm{T}_{\mathrm{e}} /\left(2 \mathrm{~m}_{\mathrm{H} 2}\right)\right)^{1 / 2}$. Each neutral brings the energy of $\mathrm{T}_{\mathrm{e}}$ to the metal and bounces back with an energy of the surface, which is much small than plasma temperature. Therefore, the power deposited by neutrals to the filament can be estimated as $\mathrm{P}_{\mathrm{H} 2}=\mathrm{dN} / \mathrm{dt} \cdot \mathrm{T}_{\mathrm{e}} \sim \mathbf{5 0 0 W}$ per filament.

The arc current heats the plasma. We assume that the electrons lose their energy through collisions and thermalize before they reach the wall. Only thermal electrons reach the wall of the plasma chamber to satisfy the charge neutrality (zero net current through plasma). The power deposited by the arc into the plasma is $\mathrm{P}_{\mathrm{a}}=\mathrm{I}_{\mathrm{e}} \mathrm{V}_{\mathrm{a}} \sim 70 \mathrm{~A} \times 140 \mathrm{~V} \sim 10 \mathrm{~kW}$.

The plasma loses power due to the flux of electrons to the chamber wall. The current of electrons is equal to the arc current $I_{a}$. Ions are not expected to flow to the wall. That requires the difference in potential between the wall and the plasma so that the net current through plasma sheath is zero in the absence of arc. As a result, the wall has the potential of $\sim \mathrm{T}_{\mathrm{e}}$ compared to plasma to repel ions. Then the each electron which reaches the wall has the energy of $\sim 2 \mathrm{~T}_{\mathrm{e}}$. Then the energy deposited from plasma to the chamber wall is $\mathrm{P}_{\text {arc-to-wall }} 2 \mathrm{~T}_{\mathrm{e}} \cdot \mathrm{I}_{\mathrm{a}} / \mathrm{e} \sim \mathbf{1 8 0 W}$.

Neutrals are expected to bring energy to the plasma chamber wall, similar to what has been discussed for filament. One just should take into account that the surface area of the wall $2 x \pi \cdot 5 \mathrm{~cm} \cdot 15 \mathrm{~cm}$ is significantly different from the surface area of the filament. As a result, the power deposited by neutrals to the wall is

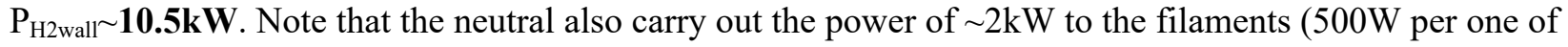
4 filaments).

The plasma is hot during the arc. The power of thermal radiation can be estimated as the power of the bremsstrahlung radiation caused by e-e collisions in plasma. The power of the radiation is well known and can be found, for example in Ref. [31]. This power can be estimated as $\mathrm{P}_{\mathrm{b}} \sim 1.7 \cdot 10^{-27} \cdot\left(\mathrm{T}\left[{ }^{\circ} \mathrm{K}\right]\right)^{1 / 2} \cdot\left(\mathrm{n}_{\mathrm{e}}\left[\mathrm{cm}^{-3}\right]\right)^{2} \cdot \mathrm{V}$ $\mathrm{erg} / \mathrm{s}$. For the plasma parameters of interest, the radiation losses of plasma can be estimated to be $\mathrm{P}_{\mathrm{b}} \sim 0.7 \cdot 10^{-4}$ W. Estimates show that the plasma is heated by the arc current and it is cooled by the flux of hot neutrals to the wall. Additional heating from light emission from the filament is also absorbed by the plasma chamber wall. 
Thus, in summary, the total plasma power delivered to all four filaments is $\sim 4.5 \mathrm{~kW}$. The total heat load on the filaments including the contribution of DC filament power supply is then $\sim \mathbf{8} \mathbf{k W}$ and the total power delivered to the plasma chamber wall is $\sim \mathbf{1 1} \mathbf{k W}$ which is dominated by neutral flux heating.

\subsubsection{Thermal loading of the plasma chamber}

The plasma chamber from the conventional baseline D-Pace source was modelled using ANSYS. As seen in Fig.13, a STEP file was obtained from D-Pace and imported into ANSYS and heating and water flow conditions were applied. The plasma heat flux calculated in the previous section was used as a surface heat load uniformly applied to the interior of the Cu plasma chamber $(\phi=10 \times 1=15 \mathrm{~cm})$. Water cooling was also applied in the cooling channel surrounding the inner chamber wall at flow rates in the range of the D-Pace source specifications (see Table III). The complex water channel labyrinth was modeled as a simple concentric cylinder supporting cross flow. Fig. 14 shows resulting maximum wall temperature as a function of water flowrate and thermal load. We see, in principle, such a plasma chamber could easily support the $<$ $20 \mathrm{~kW}$ heat loads associated with source operation in the regime of the TRIUMF $60 \mathrm{~mA}$ experiment.

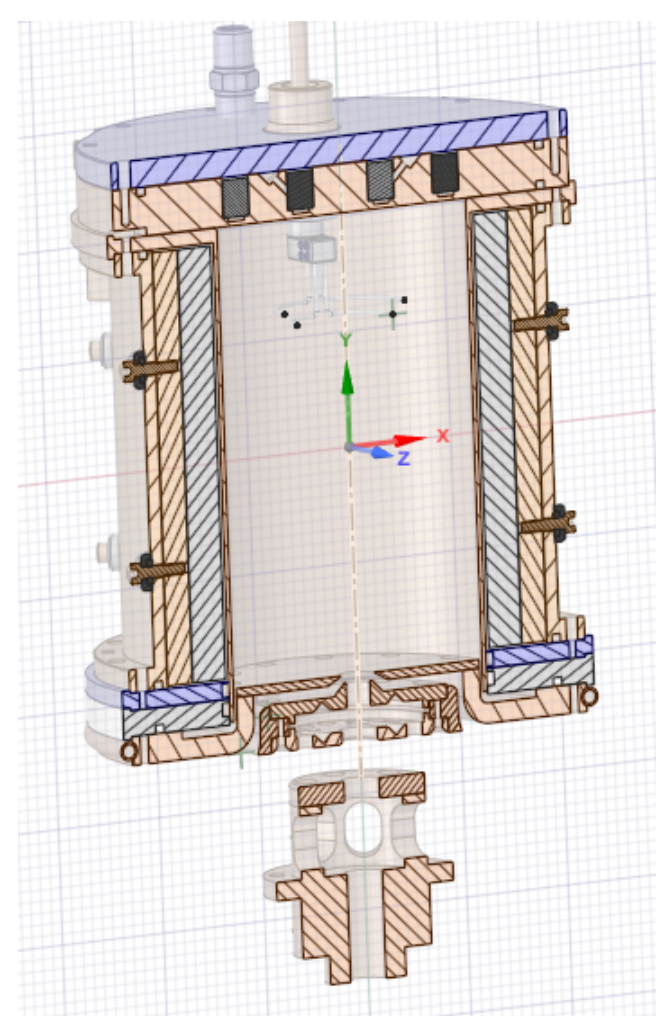

(a)

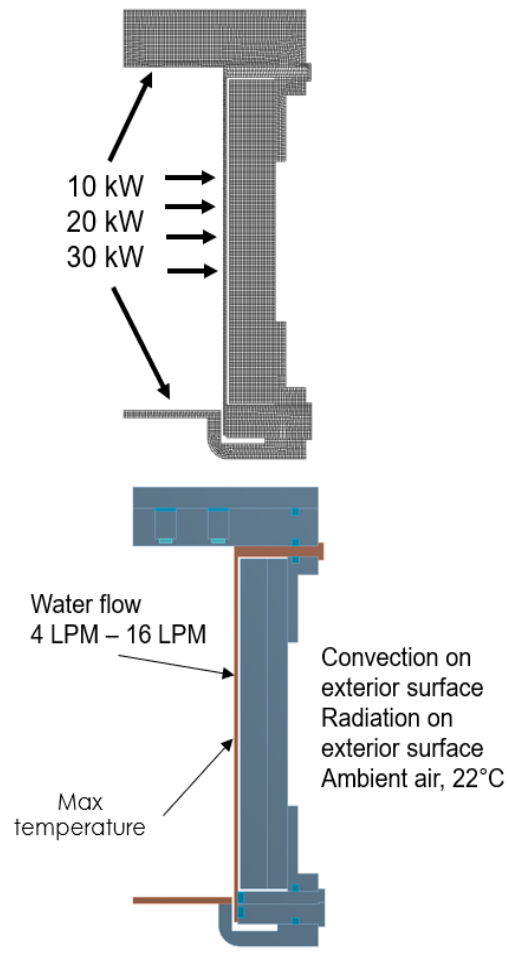

(b)

Fig. 13. (a) D-Pace plasma chamber STEP file imported to ANSYS. Heat loads and flow conditions applied to the ANSYS model. 


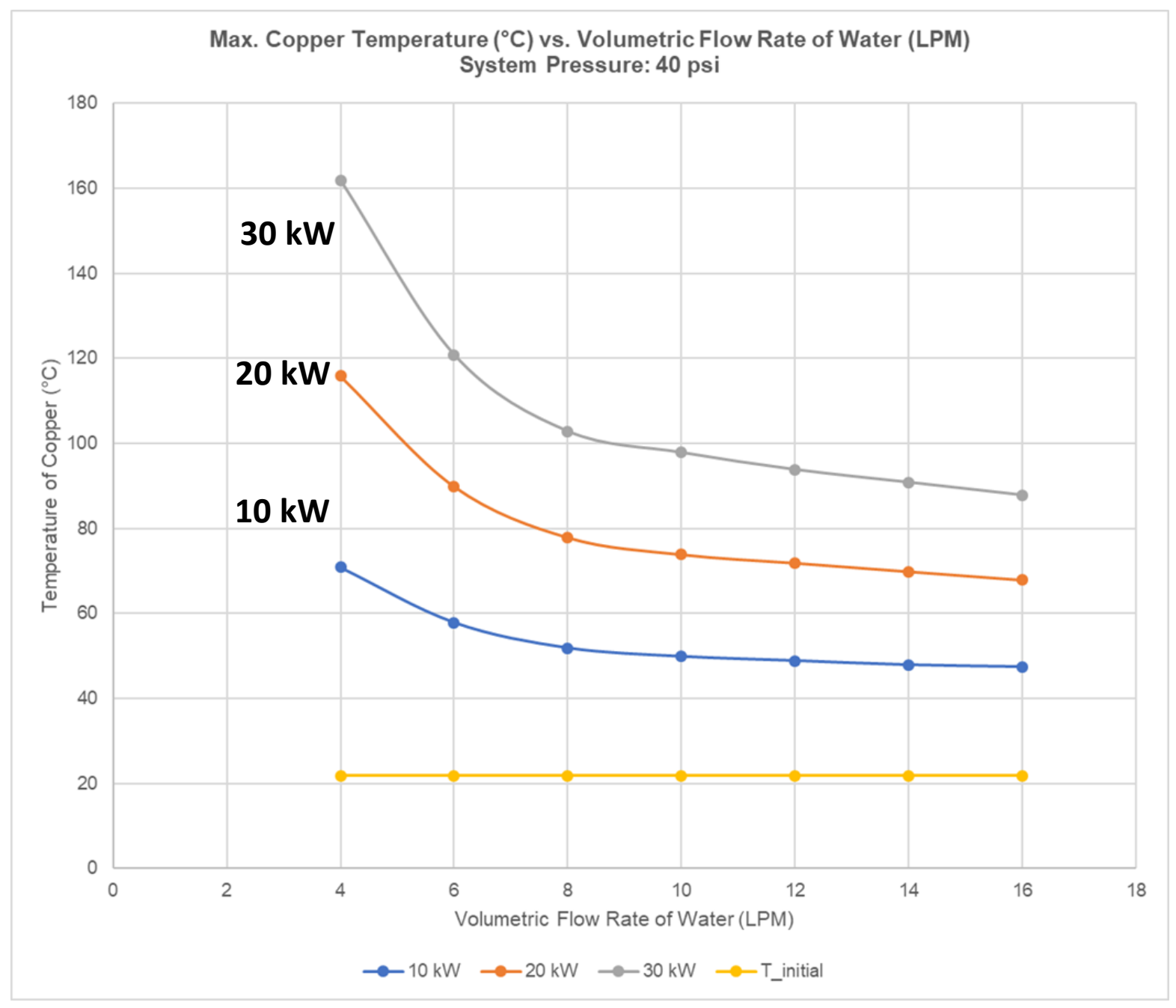

Fig. 14. Maximum temperature of the cylindrical copper plasma chamber wall as a function of the cooling water flow-rate and total chamber heat load

\subsubsection{Thermal loading and expected lifetime of the filament array}

The ANSYS finite element code was also used to estimate the radiative cooling power of the 4-filament array shown in Fig. 7a. Uniform heat loads of $0-20 \mathrm{~kW}$ were applied to the filaments which were primarily cooled through simple black body radiation. Fig. 15 shows the resulting relationship between heat load and average temperature of the filaments. Modeling showed that under the conditions of the TRIUMF experiment $(\sim 4.5 \mathrm{~kW}$ heat load) thermal run-away did not occur and still required significant primary heating from the filament power supply to achieve nominal emission temperatures of $\sim 2650 \mathrm{~K}[25]$.

LANL has developed a series of analytical, empirical and numerical models for filament lifetime which have been successfully used to model the LANSCE ion source [25]. The models calculate the relative resistance of the filament as it ages due to sputtering and evaporation. Operational experience at LANSCE suggests that when the filament resistance increases due to age by $\sim 12 \%$ and the filament should be 
replaced. This approach was applied to the filament array shown in Fig. 7a under the conditions of the TRIUMF experiment using a typical filament current of $400 \mathrm{~A}$ and an arc current of $90 \mathrm{~A} / 140 \mathrm{~V}$. The resulting calculation shows that reliable filament lifetimes of $\sim 30$ days should be expected. This model should also prove valuable in the next project phase to optimize filament design for longer lifetimes.
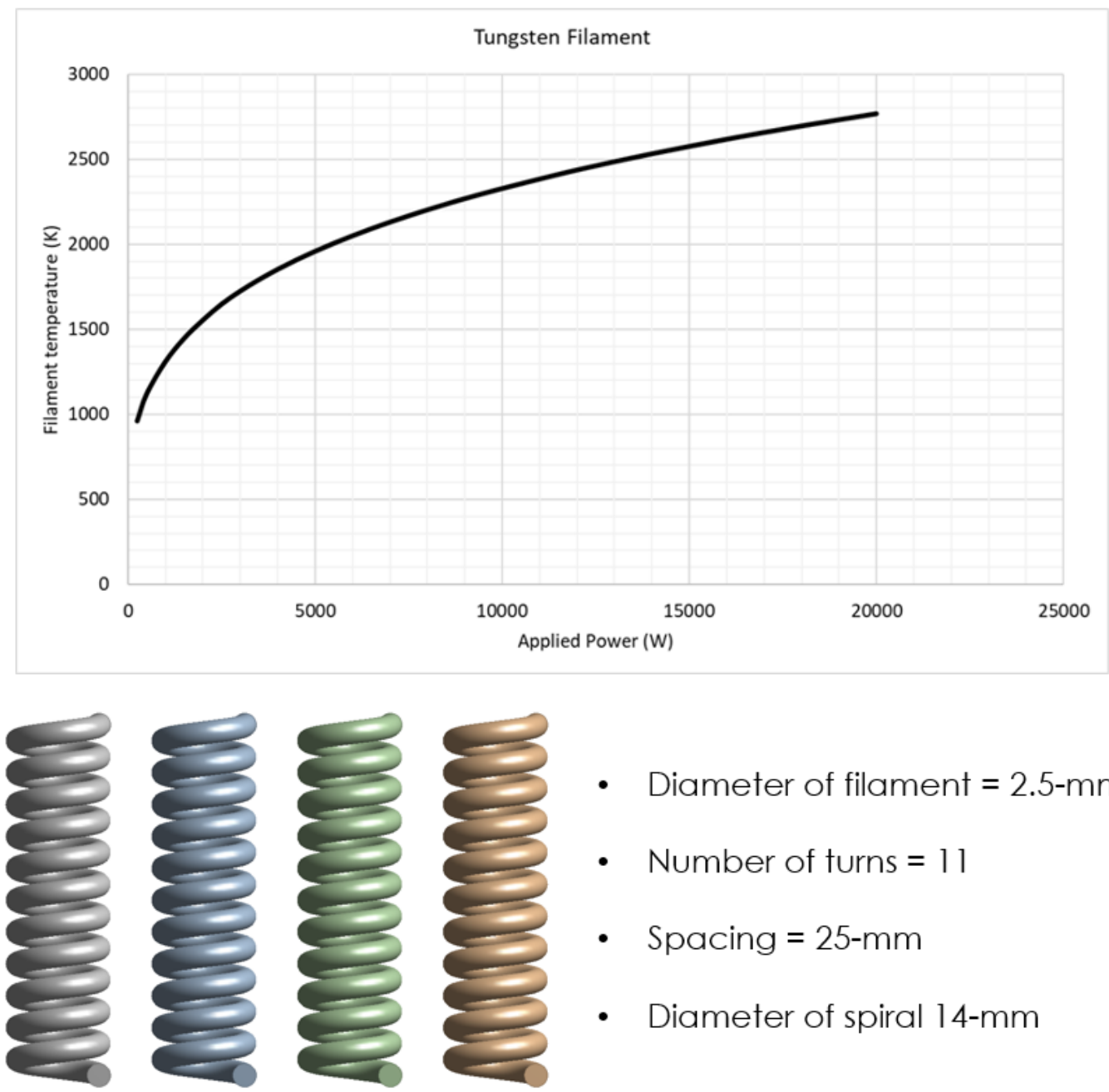

- $\quad$ Diameter of filament $=2.5-\mathrm{mm}$

- Number of turns $=11$

- $\quad$ Spacing $=25-\mathrm{mm}$

- Diameter of spiral 14-mm

Fig. 15. The relationship between the heat load (W) uniformly applied to the filament array shown in Fig. 7a. and the resulting temperature $(\mathrm{K})$ assuming simple radiation cooling is dominant. 


\subsection{Electrical Considerations}

The challenges of upgrading the electrical systems of the baseline D-Pace source to operate in the $50 \mathrm{~mA}$ $\mathrm{H}^{-}$current regime are multifold: (i) increase the capacity of the power supplies servicing the source as shown in Table VI and (ii) add a fast switch to pulse the extraction potential of this normally DC ion source (iii) increase HV source and rack isolation from $30 \mathrm{kV}$ up to $75 \mathrm{kV}$ and (iv) increase AC service to ion source systems from $\sim 20 \mathrm{kVA}$ to $\sim 60 \mathrm{kVA}$. Our analysis also suggests that the size and weight of the power supplies listed in Table VI could be reduced by $\sim 30 \%$ by removing some commercial features, using additive manufacturing to integrate cooling with the power supply electronics and magnetics and by increasing the switching frequency. In general, these power supplies are $>80 \%$ electrically efficient.

Ion source beam pulsing can be accomplished following the approach taken by FNL as well as other facilities where the voltage of the extraction electrode is pulsed [32]. We propose to use a fast Behlke $\mathrm{SiC}$ push-pull switch (see table VI) to pulse the voltage of the extraction electrode shown in Fig. 11a. An electrical schematic of the proposed configuration is shown in Fig. 16a. The LT Spice analogue circuit simulation tool was employed to determine the specifications of the switch under beam loading $(\sim 1 \mathrm{~A})$ and a 200pF capacitive load (determined from geometry) on the extractor electrode [33]. See Fig. 16b. The results of this simulation are shown in Fig. 16c: using a $500 \mathrm{ohm}$ peak limiting resistor shows that rise/fall times of $\sim 400$ ns can be realized over a wide range of repetition rates.

Table VI. Required upgrades to the D-Pace electrical system.

\begin{tabular}{|c|c|c|c|c|c|c|}
\hline & \multicolumn{2}{|c|}{$\begin{array}{c}\text { D-Pace baseline } \\
\text { configuration }\end{array}$} & \multicolumn{2}{c|}{$\begin{array}{c}\text { Proposed upgrade } \\
\text { configuration }\end{array}$} & $\begin{array}{c}\text { Rack } \\
\text { size }\end{array}$ & Weight \\
\hline Filament supply & $10 \mathrm{~V}$ & $400 \mathrm{~A}$ & $10 \mathrm{~V}$ & $1000 \mathrm{~A}$ & $3 \mathrm{U}$ & $110 \mathrm{lbs}$ \\
\hline Arc Supply & $200 \mathrm{~V}$ & $50 \mathrm{~A}$ & $150 \mathrm{~V}$ & $200 \mathrm{~A}$ & $6 \mathrm{U}$ & $170 \mathrm{lbs}$ \\
\hline Plasma supply & $20 \mathrm{~V}$ & $42 \mathrm{~A}$ & $20 \mathrm{~V}$ & $60 \mathrm{~A}$ & $1 \mathrm{U}$ & $18 \mathrm{lbs}$ \\
\hline $\begin{array}{c}\text { Extraction supply } \\
\text { HV supply }\end{array}$ & $30 \mathrm{kV}$ & $30 \mathrm{~mA}$ & $10 \mathrm{kV}$ & $400 \mathrm{~mA}$ & $2 \mathrm{U}$ & $601 \mathrm{bs}$ \\
\hline $\begin{array}{c}\text { Behlke SiC push- } \\
\text { pull switch }\end{array}$ & \multicolumn{2}{|c|}{$40 \mathrm{~mA}$} & $70 \mathrm{kV}$ & $110 \mathrm{~mA}$ & $2 \mathrm{U}$ & $601 \mathrm{bs}$ \\
\hline $\begin{array}{c}\text { AC service to ion } \\
\text { source systems }\end{array}$ & \multicolumn{2}{|c|}{$20 \mathrm{kVA}$} & $15 \mathrm{kV}$ & $150 \mathrm{~A} \mathrm{pk}$ & $1 \mathrm{U}$ & $40 \mathrm{lbs}$ \\
\hline
\end{tabular}

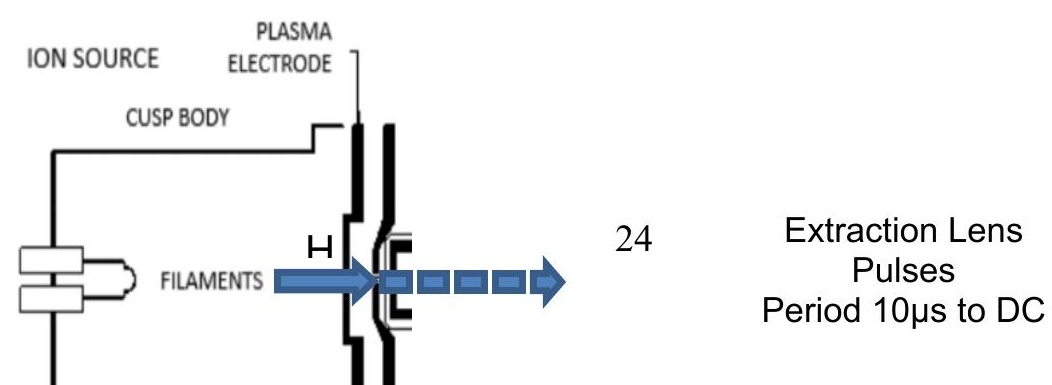




\section{$\downarrow$}

(a)

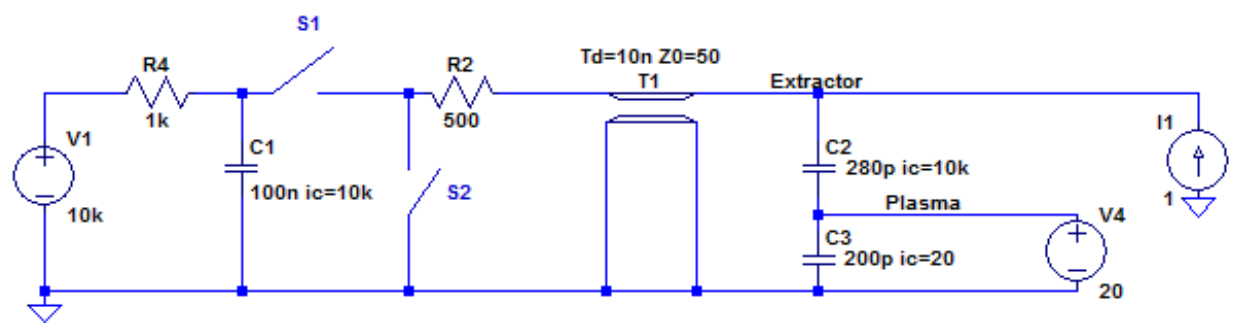

(b)

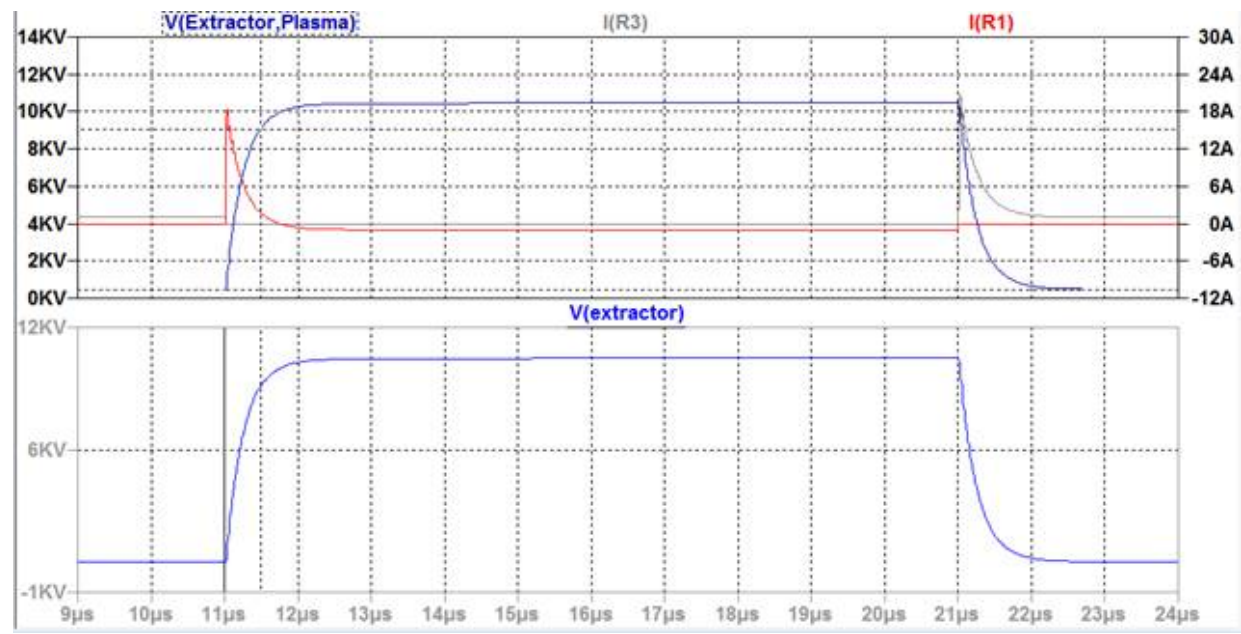

(c)

Fig. 16. (a) Schematic view of the proposed extraction system utilizing the Belkhe switch. (b) LT Spice equivalent circuit used to define the specifications of the switch. (c) LT Spice output showing $400 \mathrm{~ns}$ extractor rise and fall times under beam loading conditions. 


\subsection{Proposed Path Forward}

In this scoping study we first examined the broad landscape of existing $\mathrm{H}^{-}$ion sources and then narrowed our focus on smaller, single aperture sources which would be suitable for use with a conventional RFQ. Both pulsed and DC sources were considered and the latter was found to be capable of delivering considerably more average beam power to target. From there we quickly identified the commercially available baseline D-Pace $15 \mathrm{~mA} \mathrm{H}^{-}$source as the dominant player in this field. Although, a DC beam current of $15 \mathrm{~mA}$ is much less than the desired $100 \mathrm{~mA}$ we were, however, able to find experimental evidence that indicates DC beam currents of up to $\sim 50 \mathrm{~mA}$ could be accessible by modifying the source. In this report we also conducted plasma, beam, mechanical, thermal, fluid and electrical analysis and simulations which support our supposition that stable and long-lasting modifications can be made to the baseline D-Pace source to support these beam currents. Since, within the present state-of-the-art, there are no existing $\mathrm{H}^{-}$sources of useful emittance which have demonstrated $>15 \mathrm{~mA}$ of average current we focus on this approach.

We believe the most cost- and time-efficient path forward to realize the best possible source for the LANL NPB Project would be to develop this source through a collaboration between D-Pace, LANL and ORNL. These labs are well positioned to collaborate on manufacturing, modifying and testing a high-current version of the D-Pace source. By proposing modifications to a proven source, rather than developing a completely new design, we in effect, manage risk by placing a lower bound on the performance of the delivered ion sources. This virtually guarantees $\mathrm{H}^{-}$beams of at least $\sim 15 \mathrm{~mA},<0.2 \pi \mathrm{mm} \mathrm{mrad} \mathrm{rms}$ normalized emittance, $350+$ hour lifetime, requiring about $\sim 20 \mathrm{~kW}$ of electrical service and $15 \mathrm{SCCM} \mathrm{H}_{2}$ flow.

We believe this approach also represents the most likely path toward higher beam currents which exceed the present state of the art, capable of delivering far more average beam current than any other existing ion source technology. Furthermore, in this report, we have defined an actionable development path towards increasing the DC beam current to $\sim 50 \mathrm{~mA}$, with an emittance of $<0.3 \pi \mathrm{mm}$ mrad, requiring about $<60$ $\mathrm{kW}$ of electrical service and $\sim 30 \mathrm{SCCM}$ of $\mathrm{H}_{2}$ flow. See section 5.4.1 for details of this approach. Increasing the beam current still further may also be possible by changing outlet aperture diameter, arc power, filament structure and Cs flow.

Here is a brief summary of the desired upgrades to the baseline D-Pace source and extraction system which were identified in this study. The extraction system will have to be computationally optimized for higher beam current and energy, more aggressive water-cooling due to the increased electron dumping load. We will need the specific RFQ requirements to develop a matched system. The source back-flange will require the possible addition of a high current filament feedthrough, Cs injection port and spectroscopic viewing window (Cs diagnostic). The cooling channels of the source will possibly require modification for enhanced flow. A Cs generator / management system will need to be designed and built. Likely the filament design could also be improved. These are areas in which ORNL and LANL have considerable experience. LANL with filament modelling and design and ORNL with overall source design, LEBT design, ion optics, beam/plasma modeling, the design and operation of many difference Cs-systems as well as a strong expertise in power supplies, beam chopping and pulsed power systems. Over the years the ORNL teams has designed and operated many such source/LEBT systems installed at numerous facilities and applications [34]. 
Here is also a brief summary of the desired upgrades to the turn-key ion source testing apparatus, which consists of an electrically isolated power supply rack and a vacuum chamber, like the one shown in Fig. $7 \mathrm{~b}$. Most of the standard power supplies included with the D-Pace system will need to be upgraded as shown in Table VI. Other additions include a Behlke SiC push-pull switch and associated hardware; standard DPace emittance scanner; high-power Faraday cup as well as a downstream electron filter. In the next section 5.4.1 we present a rough schedule for the next phases of the collaboration: Development I and Development II. In 5.4.2 a preliminary first-pass cost estimate of the next phases of the project.

\subsubsection{Development I and II}

- Development II-1 (6 months): Detailed physics design of source and test chamber/stand

- ORNL designs upgrades to the D-Pace source: 2 x Physicist (1/3-FTE), 1 x Engineer (1/3FTE) and $1 \times$ Analyst (1/3-FTE)

- D-Pace designs upgrades to their turn-key test chamber/stand including upgraded power supplies, high power faraday \& associated diagnostics using TRIUMF system as a template

- Development II-2 (6 months): Detailed mechanical design of source and test chamber/stand

- ORNL provides drawing package of source upgrades to D-Pace source: 1 x Engineer (1/3FTE), 1 x Designer (1-FTE)

- D-Pace presents drawing package of test stand to ORNL for approval

- Development III-1 (6 months): D-Pace fabrication and procurement of 3 sources, 2 sets of power supplies and the test chamber/stand

- Development III-2: (6 months) Deployment, installation and startup of the test stand (upgraded DPace turn-key system) using a loaner D-Pace baseline ion source for commissioning $1 \mathrm{x}$ Physicist (1-FTE), 1 x Technician (1-FTE)

- Development III-3: (24 months) Testing, development and characterization of the ion sources. ORNL management has approved hosting the facility here

- Labor: Post doc (1-FTE), Technician (1-FTE), Physicist (1/2-FTE)

- Space: 6x8m footprint, service $100 \mathrm{kVA}$, deionized water, plant air \& water

Labor quoted above is for ORNL staff 


\subsubsection{Preliminary Cost Estimate}

Table VII shows a first pass budget estimate to develop a high current ion source for the LANL NPB project and provide LANL with 3 fully tested and characterized ion sources. Labor, travel, material supplies, space and space set-up charges apply to ORNL while all D-Pace expenses are accounted for in the subcontractor category. The D-Pace total project cost has been equally distributed over each 6-month project phase to allow procurement of longer lead-time items early in the project schedule. Budget includes travel of ORNL staff to D-Pace and LANL.

Table VII. Preliminary total cost estimate for the LANL NPB ion source project

\begin{tabular}{|c|c|c|c|c|c|c|}
\hline & 6 Months & 6 Months & 6 Months & 6 Months & 24 Months & 48 Months \\
\hline Category & Phase II-1 & Phase II-2 & Phase III-1 & Phase III-2 & Phase III-3 & Total \\
\hline Labor & 170,000 & 170,000 & & 250,000 & 680,000 & $1,270,000$ \\
\hline Travel & 10,000 & 10,000 & 10,000 & & 10,000 & 40,000 \\
\hline Subcontractor: D-Pace & 472,500 & 472,500 & 472,500 & 472,500 & & $1,890,000$ \\
\hline Materials \& Supplies & & & & & 100,000 & 100,000 \\
\hline Other Direct Cost: Space & & & & & 100,000 & 100,000 \\
\hline Contingency (10\%) & 65,250 & 65,250 & 48,250 & 72,250 & 89,000 & 340,000 \\
\hline Total Estimated Cost & 717,750 & 717,750 & 530,750 & 794,750 & 979,000 & $3,740,000$ \\
\hline
\end{tabular}




\section{REFERENCES}

1. R Hemsworth, D. Boilson, P. Blatchford et al, "Overview of the design of the ITER heating neutral beam injectors", New J. Phys. 19, 025005, (2017)

2. M. Stockli, "Pulsed, high-current H- Ion Sources for Future Accelerators", International Committee for Future Accelerators, Beam Dynamics Newsletter, ed. Y.H. Chin, No. 73 p. 144 (2018)

3. Proceedings of the International Symposium on Negative Ions and Beams and the International Conference on Ion Sources, AIP issues: 1390, 1515, 1655, 1869, 2011 and 2052. https://aip.scitation.org/

4. J. G. Alessi, "Performance of the Magnetron $\mathrm{H}^{-}$Source on the BNL $200 \mathrm{MeV}$ Linac" in American Institute of Physics CP642, 279-81 (2002) and D. Raparia, BNL, private communication (2017).

5. P. R. Karns, D. S. Bollinger, A. Sosa, "Recent Operation of the FNAL Magnetron H- Ion Source" in American Institute of Physics CP1869, 030055-1/8 (2017) and D. Bollinger, FNAL, private communication (2017).

6. D. Faircloth and S. Lawrie, "An Overview of Negative Hydrogen Ion Sources for Accelerators", in New J. Phys. 19, (2017) and private communications (2017).

7. S. Liu, H. Ouyang, T. Huang, Y. Xiao, X. Cao, Y. Lv, K. Xue, W. Chen, "The modifications at the CSNS ion source" in American Institute of Physics CP1869, 030056-1/8 (2017).

8. A. S. Belov, O. T. Frolov, V.S. Klenov, V. P. Yakushev, "Ion Sources for linac of Moscow Institute for Nuclear Research" in Rev. Sci. Instrum. 63, 2622-4 (1992) and O.M. Volodkevich, V. N. Zubets, Yu. V. Kiselev, V. S. Klenov, "Development of Remote Control System for Hminus Ions Source of INR Linac" in Proceedings of RuPAC2014, Obninsk, Kaluga Region, Russia, 423-5 (2014).

9. R. Keller, O. Tarvainen, E. Chacon Golcher, E. G. Geros, K. F. Johnson, G. Rouleau, J. E. Stelzer, T. J. Zaugg, "H- Ion Source Development for the LANCE Accelerator Systems" in 
American Institute of Physics CP1097, 161-70 (2009) and G. Rouleau, LANL, private communication (2017).

10. M. P. Stockli, , B. X. Han, S. N. Murray Jr., T. R. Pennisi, M. Santana, C. M. Stinson, R. F. Welton, "Record Performance of and Extraction Studies with the Spallation Neutron Source $\mathrm{H}^{-}$ Injector" in American Institute of Physics CP1869, 030010-1/10 (2017).

11. H. Oguri, K. Ohkoshi, K. Ikegami, A. Takagi, H. Asano, T. Shibata, K. Nanmo, A. Ueno, K. Shinto, "Operation Status of the J-PARC RF driven $\mathrm{H}^{-}$Ion Source" in American Institute of Physics CP1869, 030053-1/7 (2017) and H. Oguri, J-PARC, private communication (2017).

12. J. Lettry et al., "CERN's Linac4 Cesiated surface $\mathrm{H}^{-}$Source" in American Institute of Physics CP1869, 030002-1/8 (2017) and J. Lettry (CERN) private communications (2017).

13. Kuo, T., et al. "On the development of a $15 \mathrm{~mA}$ direct current $\mathrm{H}-$ multicusp source." Review of scientific instruments 67.3 (1996): 1314-1316 and www.d-pace.com

14. Jayamanna, K.; Ames, F.; Bylenskii, Y.; Cojocaru, G.; Minato, B.; Lovera, M., "High brightness H- ion source for accelerators developed at TRIUMF", AIP Conference Proceedings, Volume 2052, Issue 1, id.050010 (2018)

15. Yu. I. Belchenko, A. I. Gorbovsky, A. A. Ivanov, A. L. Sanin, V. Y. Savkin, and M. A. Tiunov, "Upgrade of CW negative hydrogen ion source", AIP Conference Proceedings 1515, 448 (2013)

16. J. Zacks, I. Turner, I. Day, K. Flinders, B. Crowley, R. McAdams, "Update on Developments at SNIF”, AIP Conference Proceedings 1655, 030012 (2015)

17. D. Spence, K. R. Lykke, and G. E. McMichael, "Plasma Modified Production of High-current, High-purity cw H+, D+, and H- Beams from Microwave-driven Sources", LINAC 96 (1996)

18. H. Etoh, Y. Aoki, H. Mitsubori, Y. Arakawa, T. Mitsumoto, S. Yajima, J. Sakuraba, T. Kato, and Y. Okumura, "Development of a high current $\mathrm{H}-$ ion source for cyclotrons", Rev. Sci. Instrum. $85,02 \mathrm{~B} 107$ (2014)

19. T. Kalvas, O. Tarvainen, J. Komppula, H. Koivisto, J. Tuunanen, D. Potkins, T. Stewart, and M. P. Dehnel, "A CW radiofrequency ion source for production of negative hydrogen ion beams for cyclotrons", AIP Conference Proceedings 1655, 030015 (2015)

20. Ursal Franz, a private communication.

21. Yu. Belchenko, A. Ivanov, A. Sanin, and O. Sotnikov, "Extracted beam and electrode currents in the inductively driven surface-plasma negative hydrogen ion source", AIP Conference Proceedings 1869, 030005 (2017)

22. D. Prevost, K. Jayamanna, L. Graham, S. Varah, C. Hoehr, "New Ion Source Filament for Prolonged Ion Source Operation on A Medical Cyclotron." Instruments 3, 5 (2019)

23. S. Melanson, M. Dehnel, D. Potkins, J. Theroux, C. Hollinger, J. Martin, C. Philpott, T. Stewart, P. Jackle, P. Williams, S. Brown, T. Jones, B. Coad, and S. Withington, "A negative ion source test facility", Rev. Sci. Instrum. 87, 02B109 (2016) 
24. K. Jayamanna, F. Ames, I. Bylinskii, M. Lovera, B. Minato, “A 60 mA DC H- multi cusp ion source developed at TRIUMF", Nuclear Inst. and Methods in Physics Research, A 895, p150-157 (2018)

25. I. N. Draganic, J. F. O’Hara, and L. J. Rybarcyk, "Different approaches to modeling the LANSCE $\mathrm{H}^{-}$ion source filament performance”, Review of Scientific Instruments 87, 02B112 (2016)

26. www.far-tech.com

27. J. E. Boers, "Digital Computer Simulation of Charged Particle Beams and Electrostatic Lenses," Journal of Vacuum Science and Technology. Vol 10, Nov/Dec. 1973, pp 1120-1123

28. B.X. Han, M.P. Stockli, R.F. Welton, S.N. Murray Jr., T.R. Pennisi, and M. Santana, "Emittance Characterization of the Spallation Neutron Source H- Injector", AIP Conf. Proc. 1515, 473 (2013)

29. $\quad$ www.ansys.com

30. Nikolai Yampolsky, "Modeling the filament at LANSCE H- ion source", internal LANL report (2018).

31. www.astro.utu.fi/ $\sim$ cflynn/astroII/13.html

32. A. Shemyakin, M. Alvarez, R. Andrews, J.-P. Carneiro, A. Chen, R. D’Arcy, B. Hanna, L. Prost, V. Scarpine, and C. Wiesner, "PIP-II injector test's low energy beam transport: Commissioning and selected measurements", AIP Conference Proceedings 1869, 050003 (2017)

33. www.analog.com/en/design-center/design-tools-and-calculators/ltspice-simulator.htm

34. See for example, R.F. Welton's, Curriculum Vitae, available online. 